\title{
Conodont biostratigraphy and correlation of the San Juan Formation at the Cerro La Silla section, middle Tremadocian-lower Dapingian, Central Precordillera, Argentina
}

\author{
*Matías J. Mango', Guillermo L. Albanesi ${ }^{1}$
}

\begin{abstract}
${ }^{1}$ CICTERRA (CONICET-UNC), CIGEA, Facultad de Ciencias Exactas, Físicas y Naturales, Universidad Nacional de Córdoba, Av. Vélez Sarsfield 1699, X5016GCA, Córdoba, Argentina.

matiasjmango@gmail.com; guillermo.albanesi@unc.edu.ar
\end{abstract}

*Corresponding author: matiasjmango@gmail.com

\begin{abstract}
This study deals with the conodont biostratigraphy from the uppermost part of La Silla Formation (9.6 m) and the overlying San Juan Formation $(264.7 \mathrm{~m})$, at the Cerro La Silla section, Central Precordillera of San Juan, Argentina. The 41 samples of carbonate rocks that were digested for microfossils yielded 11,388 conodont elements corresponding to 78 species. The Paltodus deltifer deltifer Subzone of the Paltodus deltifer Zone from the Baltic biostratigraphic scheme is represented at the top stratum of the La Silla Formation and the basal part of the San Juan Formation (28.4 m), which correlates with the Macerodus dianae Zone (middle Tremadocian) of the Precordilleran and North American schemes. Following upwards, the Paroistodus proteus, Prioniodus elegans, Oepikodus evae, Oepikodus intermedius and Baltoniodus triangularis-Tripodus laevis zones (middle Tremadocian-lower Dapingian) are recorded in the San Juan Formation. The Baltoniodus triangularis-Tripodus laevis Zone is recognized from the second reef level (177.3 m from the base of the San Juan Formation) up to the top stratum in the section, in contrast to previous interpretations that assigned the referred interval to the Baltoniodus navis, Paroistodus originalis and Microzarkodina parva zones of the Baltic biostratigraphic scheme. The division of the Oepikodus evae Zone in subzones, according to its original definition for the Precordillera, is not applicable at the Cerro La Silla section due to the particular species distribution. The conodont elements show a brown alteration color (CAI 2-2.5), which indicates a burial paleotemperature of $60-155^{\circ} \mathrm{C}$ for the bearer strata.
\end{abstract}

Keywords: Biostratigraphy, Conodonts, San Juan Formation, Cerro La Silla, Ordovician, Precordillera.

RESUMEN. Bioestratigrafía de conodontes y correlación de la Formación San Juan en el cerro La Silla, Tremadociano medio-Dapingiano inferior, precordillera Central, Argentina. Este estudio presenta la bioestratigrafía de conodontes del tramo superior de la Formación La Silla (9,6 m) y la suprayacente Formación San Juan (264,7 m), en la sección del cerro La Silla, precordillera Central de San Juan, Argentina. Se procesaron 41 muestras de rocas carbonáticas para la obtención de microfósiles, las cuales proporcionaron 11.388 conodontes correspondientes a 78 especies. La subzona de Paltodus deltifer deltifer de la Zona de Paltodus deltifer del esquema bioestratigráfico de la región Baltoescandinava está representada en el techo de la Formación La Silla y en la parte basal de la Formación San Juan (28,4 m), correlacionándose con la Zona de Macerodus dianae (Tremadociano medio) de los esquemas de la Precordillera y Norteamérica. Las zonas suprayacentes de Paroistodus proteus, Prioniodus elegans, Oepikodus evae, Oepikodus intermedius y Baltoniodus triangularis-Tripodus laevis (Tremadociano medio-Dapingiano inferior) se registran en la Formación San Juan. La Zona de Baltoniodus triangularis-Tripodus laevis es reconocida desde el segundo nivel arrecifal (177,3 m desde la base de la Formación San Juan) hasta el tope aflorante en la sección, lo que difiere de interpretaciones previas que asignaban el intervalo referido a las zonas de Baltoniodus navis, Paroistodus originalis y Microzarkodina parva del esquema bioestratigráfico de la Región Baltoescandinava. La división de la Zona de Oepikodus evae en subzonas, según su definición original para la Precordillera, no es aplicable a la sección del cerro La Silla por su particular distribución de las especies. Los conodontes presentan una coloración parda (CAI 2-2,5), que indica una paleotemperatura de soterramiento de $60-155^{\circ} \mathrm{C}$ para los estratos portadores. 


\section{Introduction}

The Precordillera is located between $28^{\circ} 30^{\prime}$ and $33^{\circ} \mathrm{S}$ and $68^{\circ} 15^{\prime}$ and $69^{\circ} 45^{\prime} \mathrm{W}$, partly covering the La Rioja, San Juan and Mendoza provinces. This geological province includes extensive Paleozoic outcrops and, to a lesser extent, Mesozoic and Cenozoic rock units. On the basis of its stratigraphic and structural characteristics, the Precordillera is subdivided into three morphostructural units: Eastern (Ortiz and Zambrano, 1981), Central (Baldis and Chebli, 1969) and Western Precordillera (Baldis et al., 1982).
The Central Precordillera is composed mainly of carbonate platform deposits (Cerro Totora, La Flecha, La Silla, San Juan and Las Chacritas formations) that makes up a rock sequence of $c a$. 2,500 m thick. This represent an apparently continuous cycle (Baldis and Bordonaro, 1982) deposited under warm to temperate conditions, whose sedimentation began in the Cambrian and continued up to the Darriwilian.

The Cerro La Silla, in the Central Precordillera, is located $15 \mathrm{~km}$ southeast of Jáchal City (Figs. 1 and 2), San Juan Province. The study section can be accessed by vehicle through the National Route No. 40.

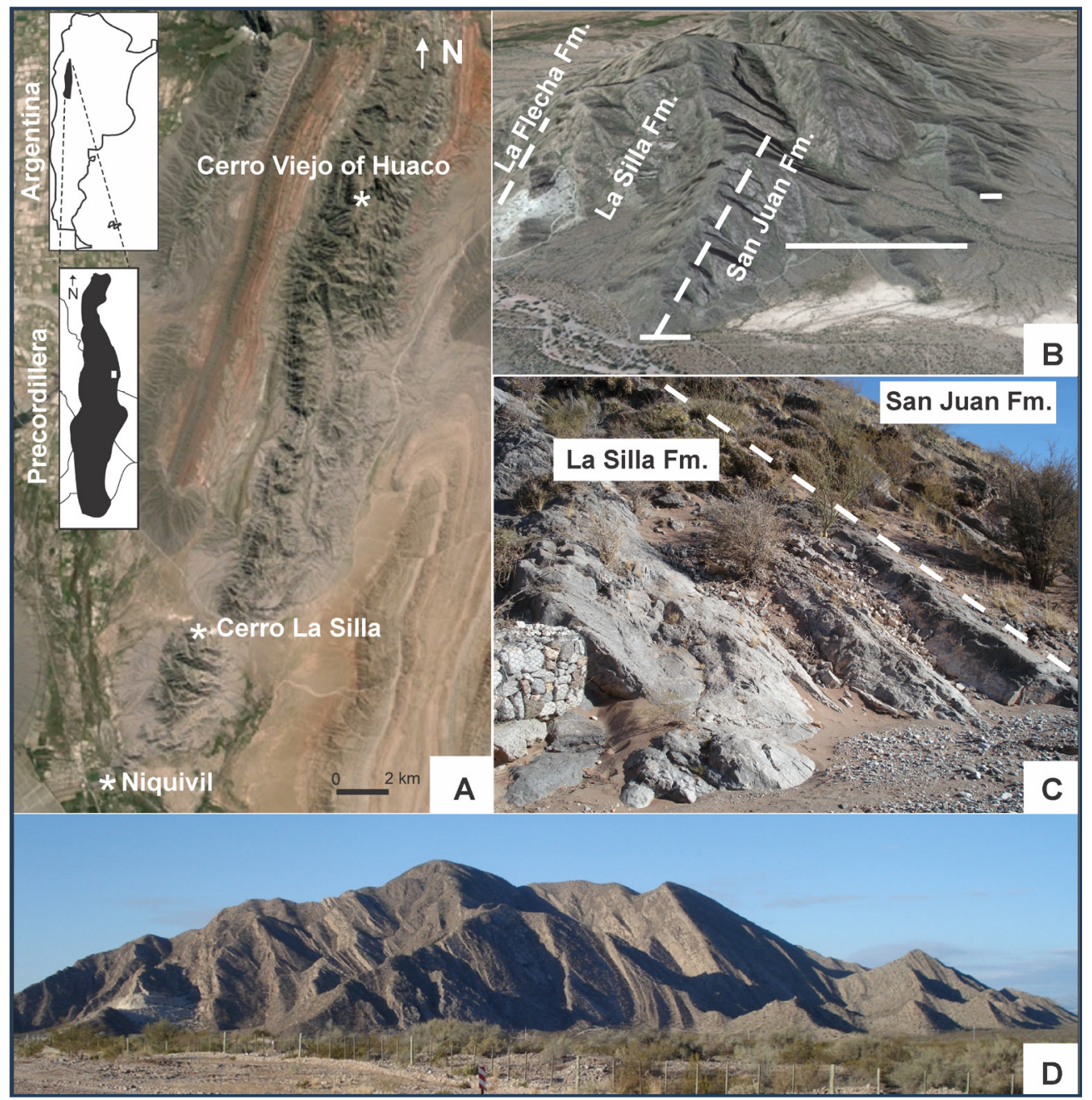

FIG. 1. A. Google Earth image showing the geographic location of the Cerro La Silla, Cerro Viejo of Huaco and Niquivil locality in the Central Precordillera. B. Google Earth image of the study area, with white lines outlining the stratigraphic sections analyzed; view to the south. C. Close up picture of the upper part of the La Silla Formation and the lower part of the San Juan Formation; view to the southwest. D. The Cerro La Silla; view to the southeast. 
The section of the San Juan Formation at the Cerro La Silla (Fig. 1) is interesting to analyze due to the presence of two reefal structures in its lower and middle parts, where a stratigraphically continuous record of the conodont fauna is represented. The upper stratigraphic section, which occupies approximately one third of its actual thickness, is covered by alluvial sediments in this locality.

The conodont biostratigraphy of the San Juan Formation at Cerro La Silla was partly studied by Lehnert (1995) and Thalmeier (2014). The biostratigraphic analysis of the uppermost part of La Silla Formation and of the overlying San Juan Formation, as well as an updating to the biostratigraphic scheme of the Precordillera (Albanesi and Ortega, 2016) motivated this work.

Accordingly, the objective of this work is to study the conodont fauna of the San Juan Formation exposed at the Cerro La Silla, including the transitional interval between this unit and the uppermost strata of the underlying La Silla Formation, in order to determine the characteristics and differences of the taxonomic record and to establish the conodont biostratigraphy following the updated biozonal scheme for the Precordillera (Albanesi and Ortega, 2016), as well as its regional and global correlation.

\section{The San Juan Formation}

The carbonate sequence of the San Juan Formation (Keller et al., 1994), approximately $330 \mathrm{~m}$ thick, is made up of skeletal micritic limestones deposited from the upper Tremadocian up to the middle Darriwilian on a ramp topography, recording two regressivetransgressive cycles (Cañas, 1995).

The boundary between the La Silla Formation and the overlying San Juan Formation marks a major change in the configuration of the carbonate platform, with the passage from subtidal to open platform facies in a carbonate ramp geometry (Pratt et al., 2012). This lithofacial change is accompanied by an important faunal change.

The limestones of the San Juan Formation starts with a transgressive sequence at whose base a reef horizon consisting of calcimicrobials and sponges is developed (Cañas and Carrera, 2003).

Subsequently, high sea level sediments accumulate (mostly bioturbated skeletal wackestones) in a framework of environmental stability, which allows the development of rich subtidal communities dominated by suspension-feeding organisms, especially brachiopods and macluritacean gastropods (Cech and Carrera, 2002).

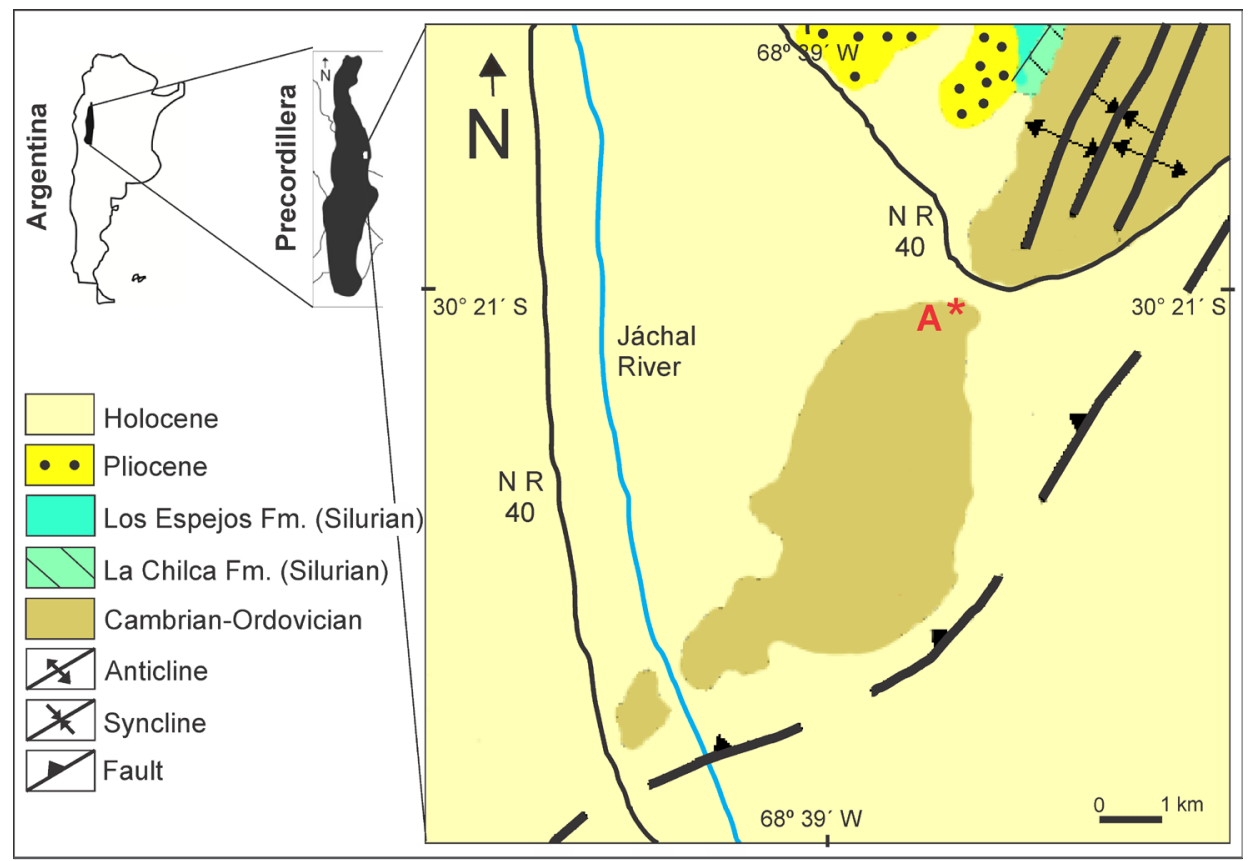

FIG. 2. Geological sketch of the study area and location of the Cerro La Silla section (A*). 
A second reef horizon that consists of microbialites, receptaculitids (Calathium) and mainly stromatoporoids (Zondarella) is located in the middle part of the San Juan Formation close to the base of the Middle Ordovician (Dapingian).

During the Darriwilian, as a consequence of a relative sea level increment that led to the drowning of the platform below the photic zone, the carbonate production is suffocated. Consequently, the carbonate cycle culminates, being followed by the deposition of calcareous-shaly facies towards a predominantly pelitic sequence (Baldis and Beresi, 1981; Baldis et al., 1984), known as the Gualcamayo and Los Azules formations in different localities of the Precordillera.

\section{Framework of the conodont biostratigraphy at the study area}

Lehnert (1995) studied the conodont biostratigraphy from the lower $130 \mathrm{~m}$ of the San Juan Formation at the Cerro La Silla section, proposing the Colaptoconus quadraplicatus-Parapanderodus striatus, Acodus? deltatus-Paroistodus proteus, Prioniodus elegansOepikodus communis, and Oepikodus evae association zones.
Subsequently, Thalmeier (2014) processed nineteen rock samples $(16.5 \mathrm{~kg})$ from San Juan Formation at the Cerro La Silla section, recovering 344 conodont elements. From this material, she recorded the Paroistodus proteus, Prioniodus elegans, Oepikodus evae, Oepikodus intermedius and Tripodus laevis zones of the biostratigraphic scheme of Albanesi et al. (1998). It should be noted that the samples from the basal strata (samples LS 8 and LS 7) were sterile, and the first productive level obtained by the author is located above the first reef level (sample LS 6).

\section{Materials and methods}

The field-work consisted in the recognition of the study area and the sampling of the stratigraphic profile corresponding to the San Juan Formation at the Cerro La Silla section. There 41 limestone samples were taken, with a variable weight between 2 and $4 \mathrm{~kg}$, among intervals of interest for the accomplishment of the present study. Thus, 2 samples were taken from the upper part of the La Silla Formation (uppermost $9.6 \mathrm{~m}$ ) and 39 samples throughout the San Juan Formation (Tables 1-4)

TABLE 1. ABSOLUTE FREQUENCY OF CONODONT SPECIES FROM THE UPPER PART OF THE LA SILLA FORMATION AND THE SAN JUAN FORMATION (SAMPLES LSLS-1 TO LSSJ P), CERRO LASILLASECTION.

Species/Samples LSLS -1 LSLS 0 LSSJ 0 LSSJ 1 LSSJ 2 LSSJ3 LSSJ 4 LSSJ P2 LSSJP1 LSSJP

\begin{tabular}{|c|c|c|c|c|c|c|c|c|c|c|}
\hline Anodontus longus & 1 & - & - & - & - & - & - & - & - & - \\
\hline Colaptoconus priscus & - & 1 & - & 2 & 1 & - & - & 2 & 1 & - \\
\hline Colaptoconus quadraplicatus & 2 & 31 & 15 & 7 & - & 1 & 5 & 1 & 4 & 4 \\
\hline Cornuodus longibasis & - & - & - & - & - & - & - & - & - & 2 \\
\hline Drepanodus arcuatus & - & - & - & - & - & 1 & 2 & - & - & - \\
\hline Drepanoistodus forceps & - & - & - & - & 1 & - & - & - & - & 5 \\
\hline Kallidontus corbatoi & - & - & - & - & - & - & - & - & 3 & - \\
\hline Lundodus gladiatus & - & - & - & - & - & - & - & - & - & 1 \\
\hline Paltodus deltifer deltifer & - & 1 & 2 & - & 1 & 3 & 1 & - & - & - \\
\hline Paltodus perrii & - & - & - & - & - & - & - & - & - & - \\
\hline Paltodus subaequalis & - & 1 & - & - & - & - & - & - & 1 & 5 \\
\hline Paroistodus proteus & - & - & - & - & - & - & - & - & 1 & 4 \\
\hline Protoprioniodus simplicissimus & - & - & - & - & - & - & - & - & - & 1 \\
\hline Scandodus furnishi & - & - & - & - & - & - & - & - & - & 1 \\
\hline Tropodus comptus & - & - & - & - & - & - & - & - & - & 1 \\
\hline Tropodus sweeti & - & - & - & - & - & - & - & - & - & 4 \\
\hline Variabiloconus bassleri & - & 2 & - & - & - & - & - & - & - & - \\
\hline Total conodont elements per sample & 3 & 36 & 17 & 9 & 3 & 5 & 8 & 3 & 10 & 28 \\
\hline Amount of processed material (g) & 2,865 & 3,740 & 2,960 & 2,405 & 2,150 & 2,035 & 2,230 & 2,005 & 2,495 & 2,075 \\
\hline Insoluble material (g) & $\mathbf{0}$ & $\mathbf{0}$ & $\mathbf{0}$ & $\mathbf{0}$ & $\mathbf{0}$ & $\mathbf{0}$ & 140 & $\mathbf{0}$ & $\mathbf{0}$ & $\mathbf{0}$ \\
\hline Soluble material (g) & 2,865 & 3,740 & 2,960 & 2,405 & 2,150 & 2,035 & 2,090 & 2,005 & 2,495 & 2,075 \\
\hline
\end{tabular}


TABLE 2. ABSOLUTE FREQUENCY OF CONODONT SPECIES FROM THE SAN JUAN FORMATION (SAMPLES LSSJ O6 TO LSSJ L3), CERRO LA SILLA SECTION.

\begin{tabular}{|c|c|c|c|c|c|c|c|c|c|c|}
\hline Species/Samples & LSSJ O6 & LSSJ 05 & LSSJ O4 & LSSJ O3 & LSSJ O2 & LSSJ O1 & LSSJ O & LSSJ N & LSSJ M & LSSJ L3 \\
\hline Acodus deltatus & - & 1 & 2 & - & 1 & - & 2 & 2 & - & - \\
\hline Anodontus longus & 2 & - & 1 & 2 & 2 & - & - & 2 & - & - \\
\hline Ansella jemtlandica & - & - & - & - & - & - & - & 1 & - & - \\
\hline Bergstroemognathus & & & & & & & & & & \\
\hline extensus & - & - & 27 & - & - & - & 18 & 9 & - & 11 \\
\hline Colaptoconus priscus & 1 & - & - & - & - & & - & - & - & - \\
\hline Colaptoconus & & & & & & & & & & \\
\hline quadraplicatus & 21 & - & - & - & - & - & - & 2 & - & - \\
\hline Cornuodus longibasis & - & - & 1 & 1 & - & 2 & 5 & 18 & 4 & - \\
\hline Diaphorodus russoi & 3 & - & 9 & 8 & 3 & 1 & 88 & 24 & 4 & - \\
\hline Diaphorodus tovei & - & - & - & - & - & - & 18 & 18 & - & - \\
\hline Drepanodus arcuatus & 4 & 1 & 17 & 16 & 14 & 6 & 134 & 180 & 8 & - \\
\hline Drepanoistodus forceps & 2 & 2 & 4 & - & 2 & - & 49 & 14 & 1 & 2 \\
\hline Gen. et sp. nov. & - & - & - & - & - & - & - & 1 & 2 & - \\
\hline Juanognathus jaanussoni & - & 3 & - & - & - & - & - & - & - & 1 \\
\hline Juanognathus variabilis & - & - & - & - & - & - & - & 3 & 2 & 15 \\
\hline Jumudontus gananda & - & - & - & - & - & - & 5 & 4 & - & - \\
\hline Kallidontus corbatoi & - & - & - & - & 1 & - & - & 1 & 2 & - \\
\hline Kallidontus princeps & - & - & - & - & - & - & 1 & - & - & - \\
\hline Kallidontus? lofgreni & - & - & - & - & - & - & 1 & - & - & - \\
\hline Lundodus gladiatus & - & 4 & - & - & - & - & - & 4 & - & - \\
\hline Oelandodus costatus & - & 3 & - & 6 & - & 1 & 5 & 18 & 3 & 4 \\
\hline Oelandodus costatus? & - & - & - & 1 & - & - & - & 4 & - & - \\
\hline Oelandodus elongatus & - & 1 & 9 & - & 13 & - & 159 & 233 & 4 & - \\
\hline Oepikodus communis & - & - & - & - & - & - & 7 & 3,444 & 5 & - \\
\hline Oistodus lanceolatus & - & - & - & - & - & - & - & - & 12 & - \\
\hline Oistodus multicorrugatus & - & - & - & 1 & - & - & - & - & 1 & - \\
\hline Paltodus perrii & - & - & 3 & - & - & - & 4 & 9 & - & - \\
\hline Paltodus subaequalis & 4 & 1 & 8 & 14 & 2 & - & 39 & 50 & 6 & - \\
\hline Paracordylodus gracilis & - & - & 4 & 1 & - & 1 & 70 & 1 & - & - \\
\hline $\begin{array}{l}\text { Parapaltodus } \\
\text { simplicissimus }\end{array}$ & - & 1 & - & 1 & 4 & - & - & - & 2 & - \\
\hline $\begin{array}{l}\text { Parapanderodus } \\
\text { paracornuformis }\end{array}$ & - & - & - & 1 & - & - & - & - & - & - \\
\hline Paroistodus originalis & 13 & - & - & - & - & - & - & - & - & 1 \\
\hline Paroistodus parallelus & 1 & - & - & - & - & - & 2 & 10 & 4 & - \\
\hline Paroistodus proteus & - & 2 & 14 & 9 & 8 & - & 177 & 405 & 3 & - \\
\hline Periodon primus & - & 2 & 1 & - & - & - & 4 & 8 & - & - \\
\hline Periodon selenopsis & - & - & - & - & - & - & - & 4 & - & - \\
\hline Prioniodus elegans & - & 1 & 15 & - & 6 & 4 & 84 & 637 & - & - \\
\hline $\begin{array}{l}\text { Protopanderodus } \\
\text { elongatus }\end{array}$ & 2 & 1 & - & 1 & 4 & 4 & 14 & 11 & 6 & 2 \\
\hline
\end{tabular}


Table 2 continued.

Species/Samples LSSJ O6 LSSJ O5 LSSJ O4 LSSJ O3 LSSJ O2 LSSJ O1 LSSJ O LSSJ N LSSJ M LSSJ L3

Protopanderodus gradatus 3 47

Protopanderodus leonardii

Protopanderodus rectus

Protoprioniodus cowheadensis

Protoprioniodus simplicissimus Reutterodus andinus Rossodus barnesi Scandodus furnishi Scolopodus krummi

Semiacontiodus potrerillensis Tripodus albanii Tropodus australis Tropodus comptus

Tropodus sweeti

Venoistodus venustus

Total conodont elements per sample

Amount of processed material (g) Insoluble material (g) Soluble material (g)

$\begin{array}{rrrrrrrrrr}66 & 42 & 189 & 131 & 165 & 48 & 1,553 & 5,720 & 127 & 51 \\ 2,025 & 2,090 & 2,005 & 2,100 & 2,225 & 2,090 & 2,375 & 2,005 & 2,105 & 2,520 \\ 0 & 0 & 0 & 0 & 0 & 0 & 0 & 0 & 0 & 0 \\ 2,025 & 2,090 & 2,005 & 2,100 & 2,225 & 2,090 & 2,375 & 2,005 & 2,105 & 2,520\end{array}$

TABLE 3. ABSOLUTE FREQUENCY OF CONODONT SPECIES FROM THE SAN JUAN FORMATION (SAMPLES LSSJ L2 TO LSSJ I), CERRO LA SILLA SECTION.

Species/Samples

LSSJ L2 LSSJ L1 LSSJ K2 LSSJ K1 LSSJ K LSSJ J1 LSSJ J LSSJ I2 LSSJ I1 LSSJ I

Anodontus longus

Ansella jemtlandica

Bergstroemognathus extensus

Colaptoconus quadraplicatus

Cooperignathus aranda

Cornuodus longibasis

Diaphorodus russoi

Drepanodus arcuatus

Drepanoistodus basiovalis

Drepanoistodus forceps

Erraticodon patu

Fahraeusodus adentatus

Juanognathus jaanussoni

Juanognathus n. sp. A

Juanognathus variabilis

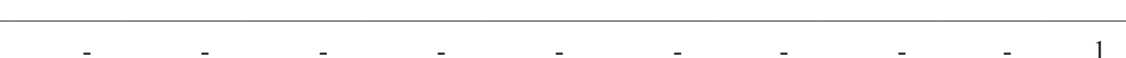


Table 3 continued.

Species/Samples

Jumudontus gananda

Kallidontus princeps

Lundodus gladiatus

Gen. et sp. nov.

Oelandodus costatus

Oelandodus elongatus

Oepikodus communis

Oepikodus evae

Oepikodus intermedius

Oistodus lanceolatus

Oistodus striolatus

Paltodus subaequalis

Paltodus? jemtlandicus

Paracordylodus gracilis

Parapaltodus simplicissimus

Parapanderodus

paracornuformis

Parapanderodus striatus

Paroistodus cf. P. proteus

Paroistodus originalis

Paroistodus parallelus

Paroistodus proteus

Periodon flabellum

Periodon primus

Periodon selenopsis

Prioniodus adami

Prioniodus elegans

Protopanderodus elongatus

Protopanderodus gradatus

Protopanderodus leonardii

Protopanderodus rectus

Pteracontiodus cryptodens

Reutterodus andinus

Rossodus barnesi

Scolopodus krummi

Scolopodus oldstockensis

Texania heligma

Trapezognathus diprion

Triangulodus brevibasis

Tropodus australis

Tropodus comptus

Tropodus sweeti

Total conodont elements per sample

Amount of processed material (g)

Insoluble material (g)

Soluble material (g)

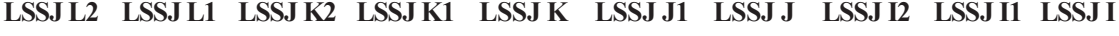

\begin{tabular}{|c|c|c|c|c|c|c|c|c|c|}
\hline- & - & - & - & - & 1 & - & - & - & - \\
\hline- & - & - & 1 & - & - & - & - & - & - \\
\hline- & - & - & 1 & 6 & 1 & - & 1 & - & 1 \\
\hline- & - & - & - & - & - & - & 1 & - & - \\
\hline- & 1 & - & - & 3 & - & - & - & - & 1 \\
\hline- & 1 & 1 & - & - & - & - & - & & - \\
\hline 4 & - & 41 & - & - & - & - & - & - & - \\
\hline - & - & 25 & 10 & 136 & 3 & - & - & - & - \\
\hline- & - & - & 1 & 43 & - & 1 & 6 & 196 & 80 \\
\hline- & - & - & - & - & - & 2 & - & 7 & 39 \\
\hline- & - & - & - & - & - & - & - & 1 & - \\
\hline 1 & 1 & 2 & 3 & 19 & 4 & - & 1 & 4 & 3 \\
\hline- & - & - & - & - & - & - & - & - & 1 \\
\hline- & - & - & - & 1 & - & - & - & - & 1 \\
\hline 3 & 1 & - & 1 & - & - & - & - & - & - \\
\hline- & - & - & - & - & - & - & - & - & 1 \\
\hline 3 & - & - & - & - & - & - & - & - & - \\
\hline - & - & - & - & 29 & - & - & - & - & 2 \\
\hline- & - & 2 & 7 & - & - & - & 6 & 20 & 5 \\
\hline- & - & - & 1 & 2 & 3 & - & - & - & 1 \\
\hline 1 & - & - & - & - & - & - & - & - & - \\
\hline- & - & 4 & - & 31 & - & 2 & 5 & 3 & 72 \\
\hline- & - & - & - & 29 & - & - & - & - & - \\
\hline 4 & - & 1 & - & - & 2 & - & - & - & - \\
\hline - & - & - & - & - & - & - & - & 4 & - \\
\hline 17 & - & 2 & - & - & - & - & - & - & - \\
\hline 15 & 1 & - & 7 & - & - & - & - & 14 & 2 \\
\hline 3 & 1 & 15 & - & 21 & 16 & - & 7 & 9 & 94 \\
\hline 23 & 1 & 3 & 14 & 16 & 7 & 4 & - & - & 14 \\
\hline 2 & - & 16 & 13 & 50 & - & 8 & 27 & 58 & 38 \\
\hline - & - & - & - & 8 & - & - & - & 1 & - \\
\hline 20 & 1 & 18 & 11 & 39 & 5 & 12 & - & - & - \\
\hline 2 & - & 8 & - & 1 & - & - & - & 7 & 16 \\
\hline 1 & - & 27 & - & 6 & 15 & 1 & - & - & - \\
\hline- & - & 5 & 5 & 1 & 4 & 1 & - & - & 2 \\
\hline- & - & 1 & - & - & - & - & - & - & 2 \\
\hline- & - & - & - & - & - & - & - & 1 & - \\
\hline - & - & - & - & - & - & - & - & - & 3 \\
\hline 10 & - & - & - & 1 & - & - & - & - & - \\
\hline 1 & - & 1 & 1 & 4 & - & - & - & - & - \\
\hline 16 & 5 & 5 & 36 & 5 & - & 5 & - & - & 1 \\
\hline 244 & 35 & 285 & 227 & 659 & 121 & 92 & 80 & 435 & 542 \\
\hline 1,975 & 2,075 & 2,140 & 2,155 & 2,080 & 2,120 & 2,055 & 2,010 & 2,105 & 2,175 \\
\hline 0 & 0 & 0 & 0 & 0 & 0 & 0 & 0 & 0 & 0 \\
\hline 1,975 & 2,075 & 2,140 & 2,155 & 2,080 & 2,120 & 2,055 & 2,010 & 2,105 & 2,175 \\
\hline
\end{tabular}


TABLE 4. ABSOLUTE FREQUENCY OF CONODONT SPECIES FROM THE SAN JUAN FORMATION (SAMPLES LSSJ H4 TO LSSJ TOPE+), CERRO LA SILLA SECTION.

\begin{tabular}{|c|c|c|c|c|c|c|c|c|c|c|c|}
\hline Species/Samples & LSSJ H4 & LSSJ H3 & LSSJ H2 & LSSJ H1 & LSSJ H & LSSJ G & LSSJ F & LSSJ D & LSSJ B & LSSJ A+7 & $\begin{array}{l}\text { LSSJ } \\
\text { tope+ }\end{array}$ \\
\hline Anodontus longus & - & - & - & - & 1 & 1 & - & 1 & 1 & - & 1 \\
\hline Ansella jemtlandica & - & - & - & - & - & - & - & 2 & - & 2 & - \\
\hline $\begin{array}{l}\text { Bergstroemognathus } \\
\text { extensus }\end{array}$ & 1 & 6 & - & - & - & - & - & - & - & - & - \\
\hline Cornuodus longibasis & 1 & 4 & - & 1 & - & - & 2 & 2 & - & 2 & - \\
\hline Diaphorodus russoi & - & 1 & - & - & - & - & - & 1 & - & - & - \\
\hline Drepanodus arcuatus & 6 & 16 & - & 7 & - & - & - & 1 & - & - & 1 \\
\hline Drepanoistodus & & & & & & & & & & & \\
\hline basiovalis & - & - & 1 & - & - & - & 1 & 2 & 1 & - & 2 \\
\hline Drepanoistodus costatus & - & - & - & - & - & - & 1 & - & - & 2 & - \\
\hline Drepanoistodus forceps & - & 1 & - & 2 & - & - & - & - & - & - & - \\
\hline Juanognathus & & & & & & & & & & & \\
\hline jaanussoni & - & 12 & 1 & 1 & - & 1 & 2 & 8 & 14 & 18 & 18 \\
\hline Juanognathus serratus & - & - & - & - & - & - & - & - & - & 3 & 2 \\
\hline Juanognathus variabilis & - & 7 & - & - & - & - & - & - & - & - & - \\
\hline Jumudontus gananda & - & 1 & - & - & - & - & - & - & - & - & - \\
\hline Lundodus gladiatus & - & - & - & - & 1 & - & 1 & - & - & - & - \\
\hline Oelandodus elongatus & 2 & - & - & - & - & 1 & - & - & 1 & - & - \\
\hline Oepikodus intermedius & 6 & 7 & - & 1 & - & - & - & 2 & - & - & - \\
\hline Oistodus lanceolatus & 6 & 1 & - & 1 & - & - & - & 13 & - & 1 & - \\
\hline $\begin{array}{l}\text { Oistodus } \\
\text { multicorrugatus }\end{array}$ & - & 5 & - & 3 & - & - & - & - & - & - & - \\
\hline Oistodus striolatus & - & - & - & - & - & - & - & - & - & - & 3 \\
\hline Paltodus subaequalis & 3 & 4 & - & 2 & - & - & - & - & - & - & - \\
\hline Paltodus? jemtlandicus & - & - & - & - & - & - & - & - & - & 1 & - \\
\hline $\begin{array}{l}\text { Parapaltodus } \\
\text { simplicissimus }\end{array}$ & - & 4 & - & - & - & - & - & 1 & - & - & 2 \\
\hline $\begin{array}{l}\text { Parapanderodus } \\
\text { paracornuformis }\end{array}$ & - & - & - & - & - & - & - & - & - & - & 8 \\
\hline Paroistodus originalis & 6 & 5 & - & 10 & - & - & - & - & - & - & - \\
\hline Paroistodus parallelus & 3 & 2 & - & - & - & - & - & - & - & - & - \\
\hline Periodon flabellum & 2 & 10 & - & 2 & - & - & 1 & 2 & 1 & 1 & - \\
\hline Periodon selenopsis & - & 3 & - & - & - & - & - & - & - & - & - \\
\hline $\begin{array}{l}\text { Protopanderodus } \\
\text { elongatus }\end{array}$ & - & 7 & - & - & - & - & - & - & - & - & - \\
\hline $\begin{array}{l}\text { Protopanderodus } \\
\text { gradatus }\end{array}$ & 15 & 7 & 1 & 5 & - & - & - & - & - & - & - \\
\hline Protopanderodus rectus & 9 & 13 & 1 & 2 & - & - & 4 & 8 & 3 & - & - \\
\hline $\begin{array}{l}\text { Pteracontiodus } \\
\text { cryptodens }\end{array}$ & - & - & - & - & - & - & - & - & 2 & - & - \\
\hline Rossodus barnesi & - & - & 1 & - & - & - & 9 & 1 & 4 & - & - \\
\hline Scalpellodus gracilis & - & - & - & - & - & - & 1 & - & - & - & - \\
\hline $\begin{array}{l}\text { Scolopodus } \\
\text { oldstockensis }\end{array}$ & - & - & - & - & - & - & - & 2 & - & - & - \\
\hline Scolopodus striatus & - & - & - & - & - & - & - & 1 & - & - & - \\
\hline $\begin{array}{l}\text { Semiacontiodus } \\
\text { potrerillensis }\end{array}$ & - & - & - & - & 1 & 1 & 1 & 2 & 16 & 6 & 4 \\
\hline Stolodus stola & - & - & - & - & - & - & - & - & - & - & 2 \\
\hline
\end{tabular}


Table 4 continued.

\begin{tabular}{|c|c|c|c|c|c|c|c|c|c|c|c|}
\hline Species/Samples & LSSJ H4 & LSSJ H3 & LSSJ H2 & LSSJ H1 & LSSJ H & LSSJ G & LSSJ F & LSSJ D & LSSJ B & LSSJ A +7 & $\begin{array}{l}\text { LSSJ } \\
\text { tope+ }\end{array}$ \\
\hline Triangulodus brevibasis & - & - & 1 & - & - & - & - & 6 & - & 4 & - \\
\hline Tripodus laevis & - & - & - & - & 1 & 1 & 5 & 2 & 2 & 3 & 2 \\
\hline Tropodus australis & 3 & 2 & - & - & - & - & - & - & - & - & - \\
\hline Tropodus comptus & - & 1 & - & - & - & - & - & - & - & - & - \\
\hline Tropodus sweeti & - & 1 & - & - & - & - & 1 & - & - & - & - \\
\hline $\begin{array}{l}\text { Total conodont } \\
\text { elements per sample }\end{array}$ & 63 & 120 & 6 & 37 & 4 & 5 & 29 & 57 & 45 & 43 & 45 \\
\hline $\begin{array}{l}\text { Amount of processed } \\
\text { material (g) }\end{array}$ & 2,005 & 2,400 & 2,105 & 2,005 & 2,255 & 2,535 & 2,310 & 2,355 & 2,295 & 2,315 & 2,770 \\
\hline Insoluble material (g) & $\mathbf{0}$ & 20 & $\mathbf{0}$ & $\mathbf{0}$ & $\mathbf{0}$ & 10 & $\mathbf{0}$ & 50 & $\mathbf{0}$ & $\mathbf{0}$ & $\mathbf{0}$ \\
\hline Soluble material (g) & 2,005 & 2,380 & 2,105 & 2,005 & 2,255 & 2,525 & 2,310 & 2,305 & 2,295 & 2,315 & 2,770 \\
\hline
\end{tabular}

The laboratory work comprised the processing of rocks for the recovery of microfossils, following the method of Stone (1987) (10\% formic acid). For each processed sample, insoluble residue was recovered varying in weight from 20 to $100 \mathrm{~g}$, regarding the composition of the limestone. Over this residue, associated microfossils were picked up, including 11,388 conodonts specimens, which correspond to 78 species (Tables 1-4), which were illustrated by conventional optical photomicrography. The conodonts are housed in the Museo de Paleontología, Universidad Nacional de Córdoba, under repository code CORD-MP.

\section{Conodonts CAI}

In the present study, the conodonts recovered from La Silla and San Juan formations present a color alteration index $(\mathrm{CAI})$ around 2 to 2.5 , which refers to burial temperatures of $60-155^{\circ} \mathrm{C}$ (Epstein et al., 1977). These values could be explained by the Niquivil tectonic thrust; that affected the easternmost part of the Central Precordillera (Voldman et al., 2010), as recorded for the San Juan Formation in the Cerro Potrerillo (Albanesi et al., 1998), Cerro Viejo of Huaco (Ortega et al., 2007; Mango and Albanesi, 2018a) and the Río Las Chacritas exposures (Serra et al., 2015).

\section{Conodont biostratigraphy and correlation}

This work follows the conodont biostratigraphic scheme proposed by Albanesi et al. (1998, 2006, 2016) and Della Costa and Albanesi (2016), for the
Argentine Precordillera, and subsequently updated by Albanesi and Ortega (2016) (Fig. 3).

\subsection{Macerodus dianae Zone}

This zone can be recorded from the lowest sample taken in the upper La Silla Formation, 9.6 m below the contact with the San Juan Formation (LSLS-1) (Fig. 4) to the sample LSSJ P1, where Paroistodus proteus (Lindström) appears in the record. These strata bear the index fossil Paltodus deltifer deltifer (Lindström) (Fig. 5) that allows to recognize the Paltodus deltifer Zone, Paltodus deltifer deltifer Subzone of the biostratigraphic scheme of Baltica, which correlates with the Macerodus dianae Zone of the scheme used in this work. In these samples, the record of Paltodus deltifer deltifer, Colaptoconus priscus (Ji and Barnes) and Colaptoconus quadraplicatus (Branson and Mehl) is frequent, and the record of Variabiloconus bassleri (Furnish) is scarce. The local thickness of this zone is $c a .38 \mathrm{~m}$.

\subsubsection{Regional correlation}

Albanesi et al. (1998) reported the Paltodus deltifer Zone in the La Silla Formation at the Portezuelo Yanso section, and correlates its upper part with the Macerodus dianae Zone. Subsequently, Albanesi et al. (2016) studied the upper part of the La Silla Formation at the Cerro Viejo of San Roque, Central Precordillera of San Juan, and recognized the index fossils Macerodus dianae in the Umango section and Paltodus deltifer deltifer from the top stratum of the La Silla Formation in the Portezuelo Jáchal section. This work allowed to recognize the Macerodus dianae Zone. 


\begin{tabular}{|c|c|c|c|c|c|c|c|}
\hline \multirow{2}{*}{ 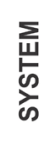 } & \multirow{2}{*}{ 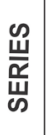 } & \multirow{2}{*}{ 岕 } & \multirow{2}{*}{ 崖嵌 } & \multicolumn{4}{|c|}{ CONODONT ZONES } \\
\hline & & & & $\begin{array}{l}\text { NORTH } \\
\text { AMERICA }\end{array}$ & BALTOSCANDIA & $\begin{array}{c}\text { ARGENTINE } \\
\text { PRECORDILLERA }\end{array}$ & $\begin{array}{l}\text { NORTHWEST } \\
\text { ARGENTINA }\end{array}$ \\
\hline & \multirow{8}{*}{$\frac{\text { U }}{\overline{\underline{0}}}$} & \multirow{4}{*}{$\mid \begin{array}{l}\bar{\alpha} \\
\frac{\alpha}{\alpha} \\
\bar{\alpha}\end{array}$} & \multirow{4}{*}{\begin{tabular}{|l}
$\frac{N}{3}$ \\
$\vdots$ \\
$\bar{z}$
\end{tabular}} & & pseudopla. & pseudopla. OZ. & \multirow{3}{*}{ "Erismodus" } \\
\hline & & & & \multirow{2}{*}{ holodentata } & \multirow{2}{*}{\begin{tabular}{|c|} 
crassus \\
variabilis \\
\end{tabular}} & crassus & \\
\hline & & & & & & variabilis $\frac{\text { nor. }}{\text { gla. }}$ & \\
\hline & & & & sinuosa & antivariabilis & \multirow{2}{*}{ parva } & \\
\hline & & & \multirow{4}{*}{ 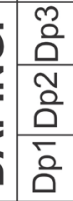 } & \multirow[b]{2}{*}{ altifrons } & norrlan./parva & & \\
\hline & & 0 & & & originalis & \multirow{2}{*}{ navis } & \multirow{2}{*}{ "B. navis" } \\
\hline & & $\bar{a}$ & & \multirow{2}{*}{$\begin{array}{l}\text { flabellum/ } \\
\text { laevis }\end{array}$} & navis & & \\
\hline & & 8 & & & triangularis & triang./laevis & B. triang. \\
\hline \multirow{14}{*}{$\begin{array}{l}z \\
\frac{z}{u} \\
\frac{3}{3} \\
0 \\
0 \\
\tilde{0} \\
0\end{array}$} & \multirow{14}{*}{$\frac{\alpha}{\underbrace{\infty}_{0}}$} & \multirow{6}{*}{$\begin{array}{l}\frac{z}{4} \\
\frac{1}{0} \\
\frac{1}{4}\end{array}$} & \multirow{3}{*}{$\begin{array}{l}\frac{m}{\square} \\
\frac{N}{\amalg}\end{array}$} & \multirow{3}{*}{ andinus } & \multirow{3}{*}{ evae } & intermedius & B. cf. triang. \\
\hline & & & & & & \multirow[b]{2}{*}{ evae var. } & T. diprion \\
\hline & & & & & & & G. andinus \\
\hline & & & & & & com. & G. vetus \\
\hline & & & $\overline{1}$ & communis & elegans & swe. & \\
\hline & & & & & elong./delt. & elong./delt. & \\
\hline & & \multirow{8}{*}{$\begin{array}{l}\frac{z}{4} \\
\frac{1}{0} \\
\frac{1}{\alpha} \\
\frac{1}{1}\end{array}$} & & & gracilis & \multirow{3}{*}{$s \int_{\frac{0}{2}}^{\frac{5}{2}}$ borealis } & \\
\hline & & & \multirow{7}{*}{$\frac{3}{5}$} & $\begin{array}{l}\text { deltatus/ } \\
\text { costatus }\end{array}$ & $\stackrel{\frac{d}{\varpi}}{2}$ Tripodus & & $\begin{array}{l}\text { P. proteus/ } \\
\text { A. apex }\end{array}$ \\
\hline & & & & & amoenus & & \\
\hline & & & & dianae & deltifer & dianae & deltifer \\
\hline & & & & & pristinus & deltifer & pristinus \\
\hline & & & & manitouensis & & & \\
\hline & & & & angulatus & angulatus & & anguratus \\
\hline & & & & fluctivagus & & & lapetognathus \\
\hline
\end{tabular}

FIG. 3. Chronostratigraphic scheme of the Tremadocian-Darriwilian stages (Lower-Middle Ordovician), with conodont zones of North America, the Baltoscandian region, the Precordillera and Northwest Argentina (modified from Albanesi and Ortega, 2016). In gray the time span considered in this work.

Voldman et al. (2013a) analyzed the conodonts of the Santa Rosita Formation in the sections of Peña Blanca and San Felipe, Santa Victoria, Cordillera Oriental of northwestern Argentina, and recorded the upper Paltodus deltifer Zone (P. deltifer deltifer Subzone), which correlates with the Macerodus dianae Zone.

From the Alfarcito and Rupasca members of the Santa Rosita Formation at Nazareno, Giuliano et al.
(2013) recognized the conodont fauna corresponding to the P. deltifer Zone; particularly, its upper part (the Paltodus deltifer deltifer Subzone) that correlates with the Macerodus dianae Zone.

In the San Jorge Formation, exposed in the central sector of the La Pampa Province, Albanesi et al. (2003) reported conodonts referred to the Baltoscandian upper $P$. deltifer Zone that correlates with the Macerodus dianae Zone. 

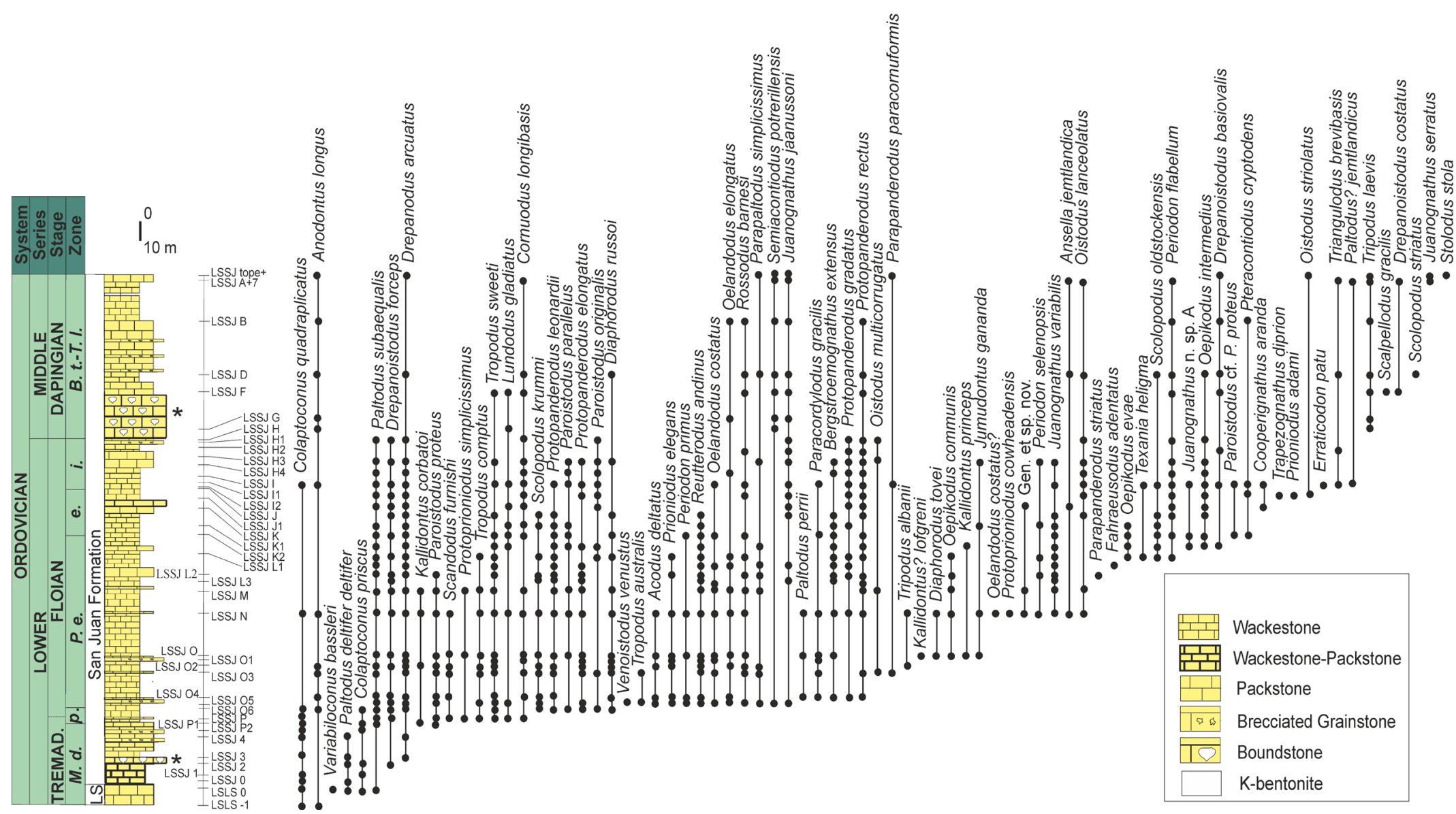

FIG. 4. Stratigraphic column from the upper part of the La Silla and San Juan formations at the Cerro La Silla sections, showing the stratigraphic distribution of conodont species (Abbreviations: LS: La Silla Formation; M.d.: Macerodus dianae; p.: Paroistodus proteus; P.e.: Prioniodus elegans; e.: Oepikodus evae; i.: Oepikodus intermedius; B.t.-T.l.: Baltoniodus triangularisTripodus laevis; *: reef level). 

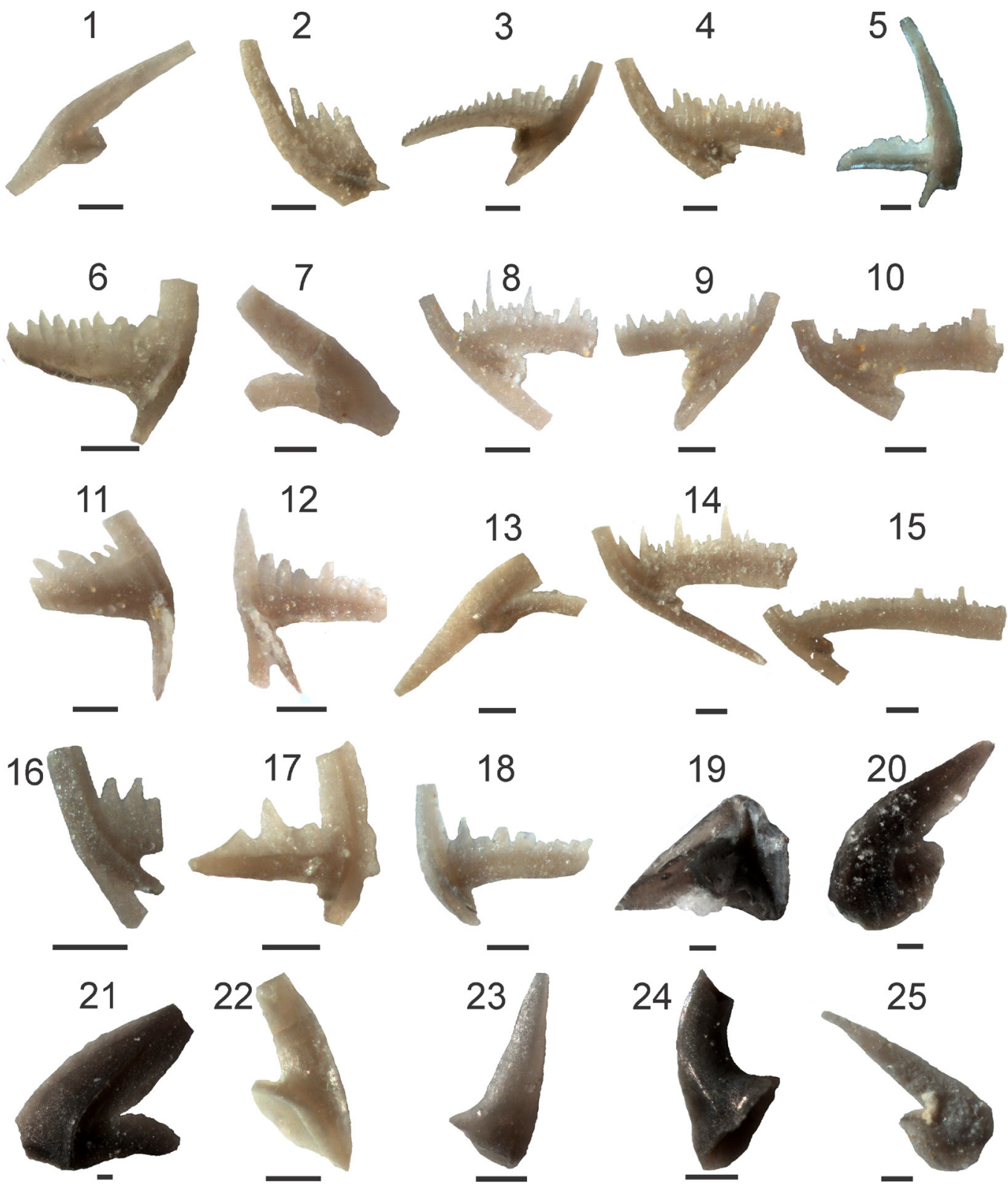

FIG. 5. Conodonts from the upper La Silla Formation and the San Juan Formation at the Cerro La Silla section. 1-6. Oepikodus communis (Ethington and Clark); 1. M element, sample LSSJ N, CORD-MP 64714; 2. Sb element, sample LSSJ N, CORDMP 64715; 3. Sc element, sample LSSJ N, CORD-MP 64716; 4. Sd element, sample LSSJ N, CORD-MP 64717; 5. Pa element, sample LSSJ O, CORD-MP 64718; 6. Pb element, sample LSSJ N, CORD-MP 64719. 7-12. Oepikodus evae (Lindström); 7. M element, sample LSSJ K, CORD-MP 68215; 8. Sb element, sample LSSJ K, CORD-MP 68216; 9. Sc element, sample LSSJ K, CORD-MP 68217; 10. Sd element, sample LSSJ K, CORD-MP 68218; 11. Pa element, sample LSSJ K, CORD-MP 68219; 12. Pb element, sample LSSJ K, CORD-MP 68220. 13-18. Oepikodus intermedius (Serpagli); 13. M element, sample LSSJ I, CORD-MP 68399; 14. Sb element, sample LSSJ I, CORD-MP 68400; 15. Sc element, sample LSSJ I, CORD-MP 68401; 16. Sd element, sample LSSJ I1, CORD-MP 68402; 17. Pa element, sample LSSJ I, CORD-MP 68403; 18. Pb element, sample LSSJ K, CORD-MP 68404. 19-21. Oistodus striolatus Serpagli; 19. Sa element, sample LSSJ tope+, CORD-MP 68824; 20. Sc element, sample LSSJ tope + , CORD-MP 68825; 21. P element, sample LSSJ tope + , CORD-MP 68826. 22-24. Paltodus deltifer deltifer (Lindström); 22. M element, sample LSLS 0, CORD-MP 68828; 23. Sa element, sample LSSJ 2, CORD-MP 68829; 24. Sb element, sample LSSJ 3, CORD-MP 68830. 25. Paroistodus proteus (Lindström), M element, sample LSSJ O, CORD-MP 69279. Scale bar: $100 \mu \mathrm{m}$. 


\subsubsection{Intercontinental correlation}

The conodont associations from the Ceratopyge limestone (lower Oelandiano AIII Stage) of Västergötland and Öland, Sweden, would correspond to the Paltodus deltifer Zone (Lindström, 1955, 1971) that in turn correlates with the Macerodus dianae Zone of the Precordillera.

Szaniawski (1980) analyzed the chalcedony layers from the Holy Cross Mountains at Poland, and divided the Paltodus deltifer Zone into two subzones, a lower or Paltodus deltifer pristinus Subzone, and an upper or Paltodus deltifer deltifer Subzone; later, Löfgren (1996) analyzed the biostratigraphy of the Orreholmen quarry in Västergötland, Sweden, recognizing this subdivision, where the upper subzone correlates with the Macerodus dianae Zone.

The Prioniodus gilberti Zone defined by Stouge and Bagnoli (1988) for layer 8 of the Cow Head Group at Newfoundland would represent the discussed zone. A correlative interval has also been identified by Smith (1991) in Greenland, Küppers and Pohler (1992) in Montagne Noire, southern France, An et al. (1983) in northern China, and by Nicoll et al. (1993) from the units underlying the Emanuel Formation in the Canning Basin of Australia.

At the Honghuayuan Formation, Guizhou, southern China, Zhen et al. (2007) record an association of conodonts that compares with material from Sweden, concluding that the lower part of that association would correspond to the P. deltifer Zone, that is partly the Macerodus dianae Zone.

\subsection{Paroistodus proteus Zone}

The index fossil Paroistodus proteus (Figs. 5-6) is recorded between the samples LSSJ P1 and LSSJ O6 (Fig. 4), immediately below the occurrence of Prioniodus elegans Pander. Its appearance in this stratigraphic interval allows the recognition of the Paroistodus proteus Zone in this section. It shall be noted that it has not been possible to identify the subzones of this zone, because the index fossils that determine these intervals have not been found. The local thickness of this zone is $7.5 \mathrm{~m}$.

The Paroistodus proteus Zone records a low diversity of conodonts at the base, with Colaptoconus priscus and C. quadraplicatus as recurrent species, ranging from the underlying zone. The diversity increases upwards towards the upper section, with the appearances of Lundodus gladiatus (Lindström), Tropodus comptus (Branson and Mehl), Tropodus sweeti (Serpagli), Cornuodus longibasis (Lindström), Protoprioniodus simplicissimus McTavish, Kallidontus corbatoi (Serpagli), Diaphorodus russoi (Serpagli), Paroistodus parallelus (Pander), Protopanderodus leonardii Serpagli, Protopanderodus elongatus Serpagli, Paroistodus originalis (Sergeeva), and Scolopodus krummi (Lehnert).

\subsubsection{Regional correlation}

Hünicken and Mazzoni (1994) reported the Paroistodus proteus Zone in the San Juan Formation from Guandacol River area of the northern Precordillera. In turn, Albanesi et al. (1998) determined the Paroistodus proteus Zone from the top strata of the La Silla Formation and the basal part of the San Juan Formation at the Yanso Section, Central Precordillera.

Voldman et al. (2016) established the Acodus apex Zone from the top stratum of the Santa Rosita Formation up to the basal part of the Acoite Formation, and the Acodus triangularis Zone from the lower part of the Acoite Formation, at the Chulpíos Creek, Santa Victoria Range, Cordillera Oriental. The Paroistodus proteus Zone of this study mostly correlates with the referred Acodus apex and A. triangularis zones.

\subsubsection{Intercontinental correlation}

Löfgren (1993) analyzed conodonts from Hunneberg, Sweden, and recognized four biostratigraphic intervals within of the Paroistodus proteus Zone, increasing the resolution for this part of the Ordovician; later, Löfgren (1994) formalized them as subzones, including the Drepanoistodus aff. D. amoenus, Tripodus, Paracordylodus gracilis and Oelandodus elongatus/Acodus deltatus subzones, from base to top, respectively.

At the Ledge Point of Head section, Cow Head Group, Newfoundland, Stouge and Bagnoli (1988) defined the Prioniodus oepiki and Prioniodus adami zones, which correlate with the upper part of the Paroistodus proteus Zone.

The discussed zone correlates with the successive zones of Scalpellodus tarsus- Triangulodus sp. aff. T. bifidus, Serratognathus bilobatus and Serratognathus extensus described for northern China (An et al., 1983; An and Zheng, 1990; Zhen et al., 2015a, 2016; Wang et al., 2018). 

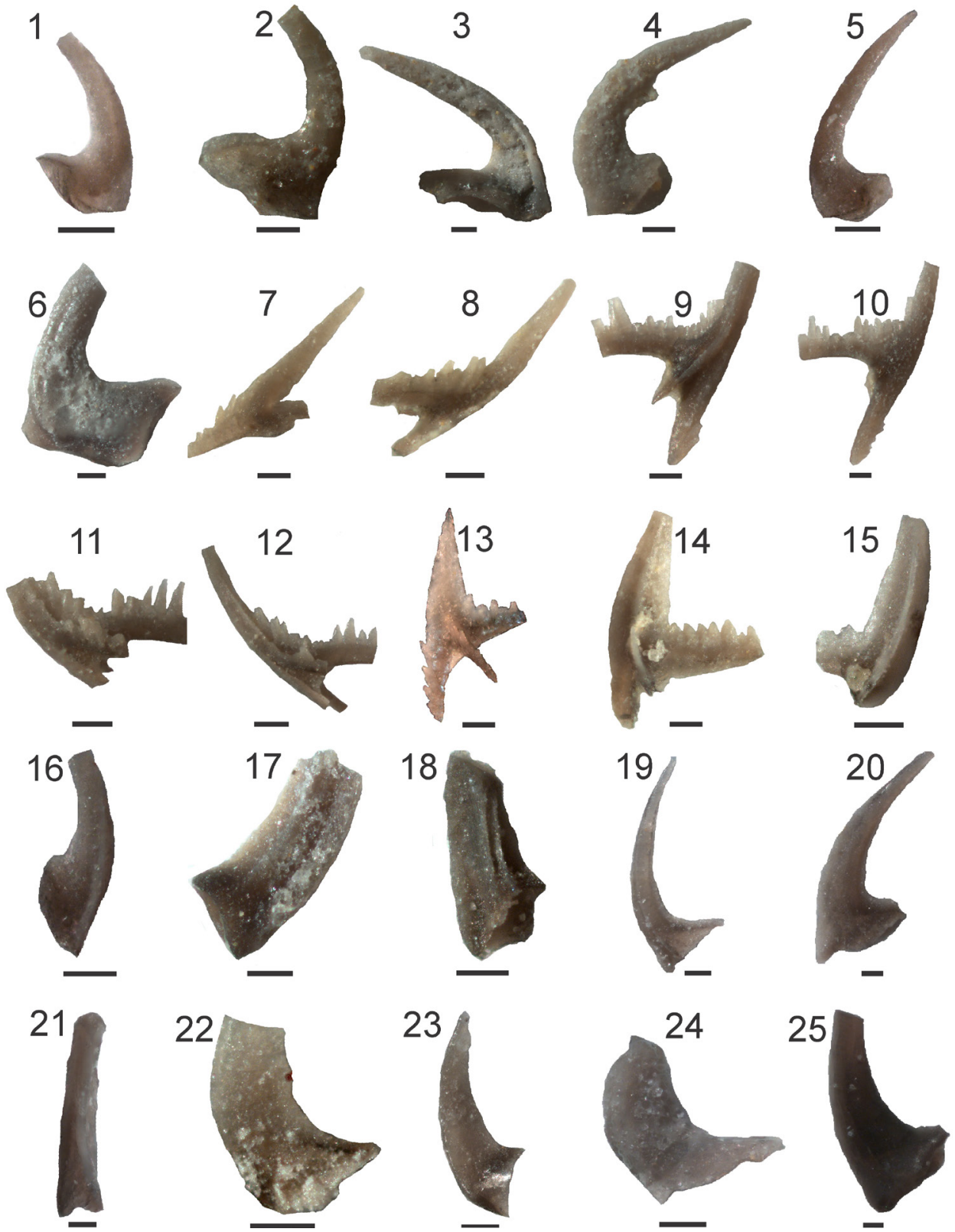

FIG. 6. Conodonts from the San Juan Formation at the Cerro La Silla section. 1-6. Paroistodus proteus (Lindström); 1. Sa element, sample LSSJ N, CORD-MP 69280; 2. Sb element, sample LSSJ O, CORD-MP 69281; 3. Sc element, sample LSSJ O, CORDMP 69282; 4. Sd element, sample LSSJ O, CORD-MP 69283; 5. Pa element, sample LSSJ N, CORD-MP 69284; 6. Pb element, sample LSSJ O, CORD-MP 69285. 7-14. Prioniodus elegans Pander; 7. M element, sample LSSJ N, CORD-MP 70101; 8. Sa element, sample LSSJ N, CORD-MP 70102; 9. Sb element, sample LSSJ N, CORD-MP 70103; 10. Sc element, sample LSSJ N, CORD-MP 70104; 11. Sd element, sample LSSJ N, CORD-MP 70105; 12. Sd element, sample LSSJ N, CORDMP 70106; 13. Pa element, sample LSSJ O, CORD-MP 70107; 14. Pb element, sample LSSJ N, CORD-MP 70108. 15-16. Pteracontiodus cryptodens (Mound); 15. Sd element, sample LSSJ I1, CORD-MP 71732; 16. P element, sample LSSJ B, CORD-MP 71733. 17-18. Scolopodus oldstockensis Stouge; 17. a element, sample LSSJ K, CORD-MP 72840; 18. e element, sample LSSJ J, CORD-MP 72841. 19-20. Triangulodus brevibasis (Sergeeva); 19. Sb element, sample LSSJ A+7, CORD-MP 72900; 20. P element, sample LSSJ A+7, CORD-MP 72901. 21-25. Tripodus laevis Bradshaw; 21. Sa element, sample LSSJ B, CORD-MP 72925; 22. Sb element, sample LSSJ D, CORD-MP 72923; 23. Sc element, sample LSSJ tope+, CORD-MP 72924; 24. Pa element, sample LSSJ tope+, CORD-MP 72926; 25. Pb element, sample LSSJ H, CORD-MP 72927. Scale bar: $100 \mu \mathrm{m}$. 
At the Honghuayuan Formation, Guizhou, southern China, Zhen et al. (2007) recorded an association of conodonts that compared with material from Sweden, concluding that the upper part of that association would correspond to the P. proteus Zone, although they did not record the index species. At slope facies of the Shijiatou and Jingshan formations, southern China, Zhen et al. (2015b) recorded the Paroistodus proteus, Triangulodus bifidus and Serratognathus diversus biozones, which correlate with the Paroistodus proteus Zone of this study.

\subsection{Prioniodus elegans Zone}

The record of Prioniodus elegans (Fig. 6) below the first appearance of Oepikodus evae (Lindström), is verified between samples LSSJ O6 and LSSJ L1 (Fig. 4), allowing for the recognition of the homonymous zone for this interval, whereas its upper limit is demarked at the sample LSSJ K2 where the Oepikodus evae index fossil appears. The Prioniodus elegans-Tropodus sweeti Subzone is recognized from sample LSSJ O6 to LSSJ O1 by the record of Tropodus sweeti not associated with Oepikodus communis (Ethington and Clark). The Prioniodus elegans-Oepikodus communis Subzone is recognized from the sample LSSJ O through the occurrence of Oepikodus communis, to the sample LSSJ K2. The local thickness of this zone is $86.6 \mathrm{~m}$.

These samples yield a high diversity and abundance of conodonts, with the record of Juanognathus jaanussoni Serpagli, Semiacontiodus potrerillensis Albanesi, Parapaltodus simplicissimus Stouge, Oelandodus elongatus (Lindström), Rossodus barnesi Albanesi, Reutterodus andinus Serpagli, Tropodus australis (Serpagli), Oelandodus costatus van Wamel, Bergtroemognathus extensus Serpagli, Acodus deltatus (Lindström), Periodon primus Stouge and Bagnoli, Ansella jemtlandica (Löfgren), Oistodus lanceolatus Pander, Parapanderodus paracornuformis (Ethington and Clark), Protopanderodus rectus (Lindström), Protopanderodus gradatus Serpagli, Paracordylodus gracilis Lindström, Oistodus multicorrugatus Harris, Periodon selenopsis (Serpagli), Jumudontus gananda Cooper, Parapanderodus striatus (Graves and Ellison) and Oepikodus communis.

\subsubsection{Regional correlation}

Serpagli (1974) suggested the existence of the Prioniodus elegans Zone in the San Juan Formation,
Precordillera, and proposed its correspondence with the Fauna A of the Pachaco section, based on the species association, although not determining the nominal species. This species was firstly published by Hünicken and Sarmiento (1980) from the Guandacol section, and the zone was defined by Albanesi et al. (1998) in the Yanso section.

Lehnert $(1993,1995)$ defined the correlative Prioniodus elegans-Oepikodus communis Association Zone for the basal levels from the San Juan Formation at the Niquivil and Cerro La Silla sections, Precordillera of San Juan.

In the Acoite Formation, Chulpíos Creek, Santa Victoria, Cordillera Oriental, Argentina, Voldman et al. (2016) established the Acodus triangularis, Gothodus vetus and Gothodus andinus zones, successively upwards. The Prioniodus elegans Zone applied in this work could be correlated with the upper part of the Acodus triangularis Zone, the Gothodus vetus Zone and much of the Gothodus andinus Zone, as defined by the referred authors.

Mango et al. (2016) studied samples from the Huaco Anticline, San Juan Precordillera, and recognized the Prioniodus elegans Zone in strata of the lower part of the San Juan Formation, based on the occurrence of the nominal species at the Río Huaco canyon.

\subsubsection{Intercontinental correlation}

Löfgren (1978, 1993, 1994, 1996) identified parts of this zone from different localities of Sweden. Layer 9 of the Cow Head Group contains conodonts assignable to the Prioniodus elegans Zone in different sections of Western Newfoundland (Fåhraeus and Nowlan, 1978; Stouge and Bagnoli, 1988; Pohler, 1994). It could also be correlated with the lower part of Fauna E proposed by Ethington and Clark (1971) for the North American biostratigraphic scheme, and with the Oepikodus communis Zone by Ethington and Repetski (1984).

The Protopanderodus inconstans-Scolopodus subrex Zone of shallow waters and Acodus delicatusAcodus? primus Zone of deep water environments defined by Ji and Barnes (1994) for the Boat Harbour Formation, Saint George Group, Newfoundland, correlate with the lower Prioniodus elegans Zone. Its upper part corresponds to the lower Parapanderodus carlae-Stultodontus ovatus Zone of shallow-water facies and to the Oepikodus communis-Protoprioniodus simplicissimus Zone of deep-water facies as defined for the Catoche Formation by the same authors. 
Seo et al. (1994) defined the Paracordylodus gracilis and Triangulodus dumugolensis zones for the upper South Korean Dumugol Formation, which could be partially correlated with the Prioniodus elegans Zone. At slope facies of the Jingshan Formation, southern China, Zhen et al. (2015b) also recorded the Prioniodus elegans Biozone.

\subsection{Oepikodus evae Zone}

This zone is recognized from the sample LSSJ K2 by the occurrence of Oepikodus evae (Fig. 5) to the sample LSSJ J (Fig. 4), where Oepikodus intermedius (Serpagli) appears not associated to Oepikodus evae. In this section, the species Juanognathus variabilis Serpagli and Scolopodus oldstockensis Stouge are recorded throughout the zonal interval, though according to the reference biostratigraphic scheme by Albanesi and Ortega (2016) it would correspond to the Oepikodus evae-Scolopodus oldstockensis Subzone of Albanesi et al. (1998). The division of the zone will be discussed in detail under the discussion part. The local thickness of this zone is $23.9 \mathrm{~m}$.

In this interval Periodon flabellum (Lindström), Drepanoistodus basiovalis (Sergeeva), Oepikodus intermedius, Scolopodus oldstockensis, Texania heligma Pohler, and Paroistodus cf. P. proteus appear in the record. Additionally, the last record of Tropodus comptus, Oepikodus communis, Prioniodus elegans and Periodon primus Stouge and Bagnoli is observed.

\subsubsection{Regional correlation}

Lehnert $(1993,1995)$ proposed the O. evae and $O$. evae./O. intermedius zones at the Niquivil section, which correlates with the $O$. evae Zone established by Albanesi et al. (1998). The later zone was recognized at the Los Gatos Creek, Cerro Viejo of Huaco, Precordillera Central of San Juan, by Mango and Albanesi (2018a).

Mestre (2008) reviewed the conodont biostratigraphy of the uppermost San Juan Formation in the Buenaventura Luna Monument area, recognizing the Oepikodus evae Zone regardless previous studies by Lemos (1981). Subsequently, Mango et al. (2016) analyzed conodonts from the Huaco Anticline, recognizing conodonts of the $O$. evae Zone from the top stratum of the San Juan Formation, and the limestone dropstones that bear the basal strata of the unconformably overlying Guandacol Formation.
Species of the Trapezognathus diprion Zone are recognized in samples obtained from the Acoite Formation of the Cordillera Oriental, Northwest Argentina by Carlorosi and Heredia (2013), whose lower part correlates with the upper O. evae Zone of Albanesi et al. (1998).

Voldman et al. (2016) define the Gothodus andinus Zone, in the upper Acoite Formation at the Chulpíos creek, Santa Victoria, Cordillera Oriental, Argentina. The upper section could be correlated with part of the O. evae Zone as used in this study. At the Suri Formation of the Famatina System (Lehnert et al., 1997; Albanesi and Astini, 2000) and the Niquivil section (Albanesi et al., 2006) the O. evae Zone is well documented.

\subsubsection{Intercontinental correlation}

The O. evae Zone can be correlated with the upper-middle part of the Oepikodus communis Zone in North American biostratigraphic schemes (Ethington and Repetski, 1984).

The index fossil has an important record in the formational units of Hubei Province in China (An, 1981; An et al., 1985), although Stouge and Bagnoli (1988) appreciate difficulty in correlation.

The Precordilleran O. evae Zone can be correlated with the O. evae Zone of Lindström (1971) and the $O$. evae Zone and the lower Trapezognathus diprion Zone of Bagnoli and Stouge (1997) from the Baltoscandian region.

In limestone blocks showing evidence of transport, contained in the Rosroe Formation, Lough Nafooey Area, Western Ireland, Stouge et al. (2015) recognize an association dominated by Oepikodus evae, Bergstroemognathus, Periodon and Protopanderodus.

\subsection{Oepikodus intermedius Zone}

The occurrence of Oepikodus intermedius (Fig. 5) not associated to Oepikodus evae and Tripodus laevis Bradshaw, allows to recognize the homonymous zone from the sample LSSJ J to the sample LSSJ H (Fig. 4), where Tripodus laevis appears in the record. The local thickness of this zone is $30.9 \mathrm{~m}$.

These samples present the first record of Triangulodus brevibasis (Sergeeva) and Paltodus? jemtlandicus Löfgren. In addition, the last record of Colaptoconus quadraplicatus, Paltodus subaequalis Pander, Drepanoistodus forceps (Lindström), Scolopodus oldstockensis, Paroistodus parallelus, 
Juanognathus variabilis Serpagli, Tropodus australis, Protopanderodus leonardii, P. elongatus, P. gradatus, Texania heligma, Paracordylodus gracilis, Paroistodus originalis, Paroistodus cf. P. proteus, Bergstroemognathus extensus, Oistodus multicorrugatus, Juanognathus n. sp. A, Scolopodus krummi, Periodon selenopsis and Jumudontus gananda is reported.

\subsubsection{Regional correlation}

At the Yanso section (Albanesi et al., 1998) and the Niquivil section (Albanesi et al., 2006) the referred unit would be correlated with the $O$. intermedius Zone. According to their collection of conodonts, the latter authors demonstrate that the Fauna $\mathrm{C}$ of the San Juan Formation (Serpagli, 1974) would represent the O. intermedius Zone, but not the Baltoniodus navis Zone as interpreted by Serpagli. At the Los Gatos Creek, Cerro Viejo de Huaco, Precordillera Central of San Juan, Mango and Albanesi (2018a) record the Oepikodus intermedius Zone in the San Juan Formation.

Carlorosi and Heredia (2013) analyzed samples obtained from the Acoite Formation, Cordillera Oriental, Northwestern Argentina, and recorded the Trapezognathus diprion Zone, and also proposed the Baltoniodus cf. B. triangularis Zone above it, which correlates with the lower and upper $O$. intermedius Zone, respectively. In the Laguna Verde section, Zenta Range, Cordillera Oriental, Northwest Argentina, Voldman et al. (2013b) recovered Baltoniodus cf. triangularis, with similar conclusions as Carlorosi and Heredia (2013).

\subsubsection{Intercontinental correlation}

The $O$. intermedius Zone could be correlated with the O. communis Zone (Ethington and Repetski, 1984; cf. Smith, 1991; Ji and Barnes, 1994), and with the Protoprioniodus aranda-Juanognathus jaanussoni interval of Ethington and Clark (1981) for the middle Wah Wah Formation of the Pogonip Group at Ibex, Utah.

The $O$. intermedius Zone correlates with the uppermost part of the Oepikodus evae Biozone of southern China and with the Jumudontus ganada Biozone of northern China (Zhen et al., 2015a, 2016; Wang et al., 2018).

In the Baltic region, it can be correlated with the upper O. evae Zone (Lindström, 1971) and with the Microzarkodina sp. A Zone of Bagnoli and Stouge
(1997). Lehnert et al. (2013) studied the biostratigraphy of the Oslobreen Group in the Svalbard archipelago, and recognized in the Valhallfonna Formation, Olenidsletta Member, the Oepikodus intermedius Zone, which would correlate with the $O$. intermedius Zone and the base of the Baltoniodus triangularisTripodus laevis Zone of this work.

\subsection{Baltoniodus triangularis-Tripodus laevis Zone}

This zone is defined by the first appearance of Tripodus laevis (Fig. 6), without being associated with Baltoniodus navis (Lindström), between samples LSSJ H and LSSJ tope+ (Fig. 4), the latter corresponds to the top stratum of the San Juan Formation in the section. At these levels, Tripodus laevis, Drepanoistodus costatus, Stolodus stola (Lindström), Pteracontiodus cryptodens (Mound), Scolopodus striatus Pander and Scalpellodus gracilis (Sergeeva) are recorded. The local thickness of this zone is at least $87.4 \mathrm{~m}$.

\subsubsection{Regional correlation}

This unit has originally been defined to as Tripodus laevis Zone in the Portezuelo Yanso section of the Cerro Potrerillo (Albanesi et al., 1998); although considering the presence of Baltoniodus triangularis (Lindström) at the same section and at Peña Sombría, Della Costa and Albanesi (2016) and Albanesi and Ortega (2016) emended the original definition by incorporating the latter taxon as composite name to the zone, for a broader reference. At the Niquivil section the referred biostratigraphic unit is correlated with the Tripodus laevis Zone (Albanesi et al., 2006) or Baltoniodus triangularis-Tripodus laevis (Mango and Albanesi, 2018b). At the Los Gatos Creek, Cerro Viejo of Huaco, Precordillera Central of San Juan, Mango and Albanesi (2018a) recorded the Baltoniodus triangularis-Tripodus laevis Zone in the San Juan Formation.

The conodont associations corresponding to Fauna D recorded at the Pachaco section on the San Juan River (Serpagli, 1974) could be assigned to the Baltoniodus triangularis-Tripodus laevis Zone.

\subsubsection{Intercontinental correlation}

This zone would correlate with the Baltoniodus? triangularis and Microzarkodina flabellum zones of Bagnoli and Stouge (1997), and with the Baltoniodus triangularis Zone of Lindström (1971) and Tolmacheva (2001), from the Baltic biostratigraphic schemes. 
In North America, it correlates with the Tripodus laevis Zone of Ross et al. (1997) and with the Microzarkodina flabellum-Tripodus laevis Zone of Ethington and Clark (1981). Ji and Barnes (1994) defined the Parapanderodus retractus Zone, for shallow-water environments, and the Pteracontiodus cryptodens Zone for deep-water environments in the Aguathuna Formation, Saint George Group, Newfoundland, correlatives of the Baltoniodus triangularis-Tripodus laevis Zone.

At the Huanghuachang section, China, it could be correlated with the Baltoniodus triangularis Zone (Wang et al., 2003). Lehnert et al. (2013) studied the biostratigraphy of the Oslobreen Group in the Svalbard Archipelago, and recognized in the Valhallfonna Formation, Olenidsletta Member, the Oepikodus intermedius Zone, whose upper part correlates with the lower Baltoniodus triangularisTripodus laevis Zone of this work.

\section{Discussion}

The $264.7 \mathrm{~m}$ thickness calculated in this work for the section of the San Juan Formation at Cerro La Silla differs from the $320 \mathrm{~m}$ estimated by Keller et al. (1994) for the same section, later used by Cañas (1999), Keller (1999), and Buggisch et al. (2003). However, the thickness calculated from the base of the San Juan Formation up to the beginning of the Oepikodus evae Zone in the Cerro La Silla section is $122.5 \mathrm{~m}$ in the present work, which coincides with the result obtained by Lehnert (1995).

At the Cerro La Silla, the division of the Oepikodus evae Zone according to its original definition is not possible to apply, due to the distribution of the species recorded. At the Portezuelo Yanso section, Scolopodus oldstockensis appears in the record next to Oepikodus intermedius in the middle Oepikodus evae Zone (Albanesi et al., 1998); instead, at the Cerro La Silla section, Oepikodus intermedius presents its first occurrence towards the middle Oepikodus evae Zone, while $S$. oldstockensis has its first occurrence in older strata at the base of the mentioned zone. The absence of S. oldstockensis in the lower Oepikodus evae Zone in the Portezuelo Yanso area could be related to facies control or a bias of the laboratory procedure.

Finally, Buggisch et al. (2003) indicated that the upper San Juan Formation at the Cerro La Silla, would correlate with the Baltoniodus navis, Paroistodus originalis, and Microzarkodina parva zones of the
Baltic biostratigraphic scheme. However, the present records constrain the deposits located from the base of the second reef level to the top stratum of the San Juan Formation exposed in the section $(87.4 \mathrm{~m})$ to the Baltoniodus triangularis-Tripodus laevis Zone.

\section{Conclusions}

The San Juan Formation at the Cerro La Silla section presents a total thickness of $264.7 \mathrm{~m}$. This result differs from published measurement that indicate a thickness of $320 \mathrm{~m}$ for the exposed strata of the formation, a significant difference possibly due to the field technique applied for measuring the thickness of this section. However, the thickness calculated from the base of the San Juan Formation up to the beginning of the Oepikodus evae Zone at this section is similar to the previously published data, as a reference for the middle part of the section.

The conodonts recovered from La Silla and San Juan formations present a color alteration index (CAI) varying from 2 to 2.5 , which refers to burial temperatures of $60-155{ }^{\circ} \mathrm{C}$ compatible with the Niquivil tectonic thrust, present in the easternmost belt of the Central Precordillera.

For the upper La Silla Formation and the lower part of the San Juan Formation at the Cerro La Silla, the Paltodus deltifer deltifer Subzone of the Paltodus deltifer Zone from the Baltic biostratigraphic scheme, which correlates with the Macerodus dianae Zone (middle Tremadocian) of the Precordillera and the North American schemes, is determined.

The San Juan Formation at the Cerro La Silla section records conodont species of the Macerodus dianae, Paroistodus proteus, Prioniodus elegans, Oepikodus evae, Oepikodus intermedius and Baltoniodus triangularis-Tripodus laevis zones (middle Tremadocian-lower Dapingian). Recovering of Baltoniodus triangularis-Tripodus laevis Zone from the second reef level to the top stratum in the section contradicts previous interpretations that this interval correlates with the Baltoniodus navis, Paroistodus originalis and Microzarkodina parva zones of the Baltic biostratigraphic scheme.

At the Cerro La Silla section, Scolopodus oldstockensis is recorded from older strata of the Oepikodus evae Zone than at the Portezuelo Yanso section, Cerro Potrerillo, where this zone was defined for the Precordillera, either because of facies control or laboratory bias. This situation precludes the application of the zonal division in the study section. 


\section{Acknowledgments}

The authors specially thank the CICTERRA (CONICET-UNC) and the CIGEA (FCEFyN, UNC) for infrastructure and equipment support. We are grateful to the CONICET and the Universidad Nacional de Córdoba, for the continuous funding to the study of conodonts. Comments and corrections by Editor W. Vivallo Sandoval and by the reviewer, Y.Y. Zhen, significantly improved our manuscript and are greatly appreciated. This contribution corresponds to part of the Doctoral Thesis in Geological Sciences of the first author.

\section{References}

Albanesi, G.L.; Astini, R.A. 2000. Bioestratigrafía de conodontes de la Formación Las Chacritas, Precordillera de San Juan, Argentina. In Reunión anual de comunicaciones de la Asociación Paleontológica Argentina, Resumen. Ameghiniana 37 (4): 68. Mar del Plata.

Albanesi, G.L.; Ortega, G. 2016. Conodont and graptolite bioestratigraphy of the Ordovician System of Argentina. In Stratigraphy \& timescales (Montenari, M.; editor) 1: 61-121.

Albanesi, G.L.; Hünicken, M.A.; Barnes, C.R. 1998. Bioestratigrafía de conodontes de las secuencias ordovícicas del cerro Potrerillo, Precordillera Central de San Juan, R. Argentina. Actas de la Academia Nacional de Ciencias, Tomo XII: 7-72. Córdoba.

Albanesi, G.L.; Bergström, S.M.; Melchor, R.N. 2003. The San Jorge Formation, La Pampa Province, Argentina, dated by means of conodonts. Ameghiniana 40 (4): 77R-78R.

Albanesi, G.L.; Carrera, M.G.; Cañas, F.L.; Saltzman, M. 2006. A proposed Global Boundary Stratotype Section and Point for the base of the Middle Ordovician Series: The Niquivil section, Precordillera of San Juan, Argentina. Episodes 29: 1-15.

Albanesi, G.L.; Cañas, F.; Mango, M. 2016. Fauna de conodontes tremadocianos del techo de la Formación La Silla en el Cerro Viejo de San Roque, Precordillera Central de San Juan. In Jornadas de Geología de Precordillera, No. 3, Acta Geológica Lilloana 28 (suplemento): 14-20. Argentina.

An, T.-X. 1981. Recent progress in Cambrian and Ordovician conodont biostratigraphy of China. In Paleontology in China, 1979 (Teichert, C.; Liu, L.; editors). Geological Society of America, Special Paper 187: 209-225.

An, T.-X.; Zheng, Z. 1990. The conodonts of the marginal areas around the Ordos Basin, north China. Science Press of China: 1-101.
An, T.-X.; Zhang, F.; Xiang, W.; Zhang, Y.; Xu, W.; Zhang, H.; Jiang, D.; Yang, C.; Lin, L.; Cui, Z.; Yang, X. 1983. The Conodonts of North China and the adjacent regions. Science Press of China: 1-223. Beijing.

An, T.-X.; Du, G.; Gao, Q. 1985. Ordovician conodonts from Hubei, China. Geological Publications House: 1-64. Beijing.

Bagnoli, G.; Stouge, S. 1997. Lower Ordovician (Billingenian-Kunda) conodont zonation and provinces based on sections from Horns Udde, north Öland, Sweden. Bolletino della Società Paleontologica Italiana 35 (2): 109-163.

Baldis, B.A.J.; Chebli, G. 1969. Estructura profunda del área central de la Precordillera sanjuanina. Cuartas Jornadas Geológicas Argentinas: 47-66.

Baldis, B. A. J.; Beresi, M. 1981. Biofacies de culminación del ciclo deposicional calcáreo del Arenigiano de oeste de Argentina. In Congreso Latinoamericano de Paleontología, No. 2, Anais 1: 11-19. Porto Alegre.

Baldis, B.A.J.; Bordonaro, O.L. 1982. Comparación entre el Cámbrico de la "Great Basin" norteamericana y la Precordillera de San Juan, Argentina, su implicancia intercontinental. In Congreso Latinoamericano de Geología, No. 5, Actas I: 97-108. Buenos Aires.

Baldis, B.A.J.; Beresi, M.; Bordonaro, O.; Vaca, A. 1982. Síntesis evolutiva de la Precordillera Argentina. In Congreso Latinoamericano de Geología, No. 5, Actas, 4: 399-445. Buenos Aires.

Baldis, B.A.J.; Beresi, M.; Bordonaro, O.; Vaca, A. 1984. The Argentine Precordillera as a key to Andean structure. Episodes 7 (3): 14-19.

Buggisch, W.; Keller, M.; Lehnert, O. 2003. Carbon isotope record of Late Cambrian to Early Ordovician carbonates of the Argentine Precordillera. Palaeogeography, Palaeoclimatology, Palaeoecology 195 (3-4): 357-373.

Cañas, F.L. 1995. Estratigrafía y evolución paleoambiental de las sucesiones carbonáticas del Cámbrico tardío y Ordovícico temprano de la Precordillera Septentrional, República Argentina. Tesis Doctoral en Ciencias Geológicas (Unpublished), Universidad Nacional de Córdoba, Facultad de Ciencias Exactas, Físicas y Naturales: $216 \mathrm{p}$.

Cañas, F.L. 1999. Facies and sequences of the Late Cambrian-Early Ordovician carbonates of the Argentine Precordillera: A stratigraphic comparison with Laurentian platforms. In Laurentia-Gondwana Connections before Pangea (Ramos, V.A.; Keppie, J.D.; editors). Geological Society of America, Special Paper 336: 43-62. Boulder, Colorado.

Cañas, F.L.; Carrera, M.G. 2003. Precordilleran reefs. In Ordovician fossils of Argentina (Benedetto, J.L.; 
editor). Secretaría de Ciencia y Tecnología, Universidad Nacional de Córdoba: 131-153.

Carlorosi, J.; Heredia, S. 2013. The conodont Trapezognathus diprion (Lindström) in the Acoite Formation, Eastern Cordillera, Northwestern Argentina. In Conodonts from the Andes. International Conodont Symposium, No. 3 (Albanesi, G.L.; Ortega, G.; editors). Asociación Paleontológica Argentina, Publicación Especial 13: 1-4.

Cech, N.; Carrera, M.G. 2002. Dinámica de las comunidades arenigianas de la Formación San Juan (Ordovícico), Precordillera Argentina. Ameghiniana 39: 21-40.

Della Costa, G.; Albanesi, G.L. 2016. Bioestratigrafía de conodontes floianos y dapingianos (Ordovícico InferiorMedio) de la Formación San Juan en la localidad de Peña Sombría, Precordillera de La Rioja. In Congreso de la Asociación Paleontológica Argentina, No. 11, Resúmenes: p. 38. Río Negro.

Epstein, A.G.; Epstein, J.B.; Harris, L.D. 1977. Conodont color alteration-an index to organic metamorphism. United States Geological Survey, Professional Paper 995: 1-27.

Ethington, R.L.; Clark, D.L. 1971. Lower Ordovician conodonts in North America. In Symposium on conodont biostratigraphy (Sweet, W.C.; Bergström, S.M.; editors). Geological Society of America, Memoir 127: 63-82.

Ethington, R.L.; Clark, D.L. 1981. Lower and Middle Ordovician conodonts from the Ibex area, western Millard County. Utah Brigham Young, University Geology Studies 28: 1-160.

Ethington, R.L.; Repetski, J.E. 1984. Paleobiogeographic distribution of Early Ordovician conodonts in central and western United States. In Conodont Biofacies and Provincialism (Clark, D.L.; editor). Geological Society of America, Special Paper 196: 89-101.

Fåhraeus, L.E.; Nowlan, G.S. 1978. Franconian (Late Cambrian) to early Champlainian (Middle Ordovician) conodonts from the Cow Head Group, western Newfoundland. Journal of Paleontology 52 (2): 444-471.

Giuliano, M.E.; Albanesi, G.L.; Ortega, G.; Zeballo, F.J.; Monaldi, C.R. 2013. Conodonts and graptolites of the Santa Rosita Formation (Tremadocian) at the Nazareno area, Santa Victoria range, Cordillera Oriental of Salta, Argentina. In Conodonts from the Andes. International Conodont Symposium, No. 3 (Albanesi, G.L.; Ortega, G.; editors). Asociación Paleontológica Argentina, Publicación Especial 13: 39-44.

Hünicken. M.A.; Sarmiento, G.N. 1980. The Baltoscandian conodont Prioniodus elegans Pander (Lower Arenigian) from the San Juan Formation of the Precordillera, Guandacol River, La Rioja, República Argentina. Academia Nacional de Ciencias, Boletín 53 (3-4): 293-306. Córdoba.
Hünicken, M.A.; Mazzoni, A. 1994. La Formación San Juan en Guandacol, provincia de La Rioja, Argentina: límites, espesor y biozonas de conodontes. In Congreso Argentino de Paleontología y Bioestratigrafía, No. 6, Resúmenes: 60-61. Trelew.

Ji, Z.; Barnes, C.R. 1994. Lower Ordovician conodonts of the St. George Group, Port au Port Peninsula, western Newfoundland, Canada. Palaeontographica Canadiana, Geological Association of Canada and Canadian Society of Petroleum Geologists, Calgary 11: 1-149.

Keller, M. 1999. Argentine Precordillera: Sedimentary and plate tectonic history of a Laurentian crustal fragment in South America. Geological Society of America, Special Paper 341: 1-131.

Keller, M.; Cañas, F.; Lehnert, O.; Vaccari, N.E. 1994. The Upper Cambrian and Lower Ordovician of the Precordillera (Western Argentina): Some stratigraphic reconsiderations. Newsletter on Stratigraphy 31 (2): 115-132.

Küppers, A.N.; Pohler, S.M.L. 1992. Discovery of the first Early Ordovician conodonts from the Montagne Noire, southern France. In Global Perspectives on Ordovician Geology (Webby, B.D.; Laurie, J.R.; editors). Balkema: 487-494. Rotterdam.

Lehnert, O. 1993. Bioestratigrafía de los conodontes arenigianos de la Formación San Juan en la localidad de Niquivil (Precordillera sanjuanina, Argentina) y su correlación intercontinental. Revista Española de Paleontología 8 (2): 153-164.

Lehnert, O. 1995. Ordovizische conodonten aus der Präkordillere westargentiniens: Ihre bedeutung für Stratigraphie und Paläogeographie. Erlanger Geologische Abhandlungen 125: 1-193.

Lehnert, O.; Miller, J.F.; Repetski, J.E. 1997. Paleogeographic significance of Clavohamulus hintzei Miller (Conodonta) and other Ibexian conodonts in an early Paleozoic carbonate platform fades of the Argentine Precordillera. Geological Society of America Bulletin 109 (4): 429-443.

Lehnert, O.; Stouge, S.; Brandl, P. A. 2013. Conodont biostratigraphy in the Early to Middle Ordovician strata of the Oslobreen Grup in Ny Friesland, Svalbard. Z. Dt. Ges. Geowiss 164: 149-172.

Lemos, V.B. 1981. Conodontes ordovicianos da Formacào San Juan, Precordillera, Departamento Jáchal, Provincia de San Juan, República Argentina (Bioestratigrafia). Anais II Congresso Latinoamericano de Paleontologia, Porto Alegre, 1: 31-43.

Lindström, M. 1955. Conodonts from the lowermost Ordovician strata of south-central Sweden. Geologiska Föreningens i Stockholm Förhandlingar 76 (4): $517-$ 604. doi: 10.1080/11035895409453581. 
Lindström, M. 1971. Lower Ordovician conodonts of Europe. In Symposium on Conodont Biostratigraphy (Sweet, W.C.; Bergström, S.M.; editors). Geological Society of America, Memoir 127: 21-61.

Löfgren, A. 1978. Arenigian and Llanvirnian conodonts from Jämtland, northern Sweden. Fossils and Strata 13: 1-129.

Löfgren, A. 1993. Arenig conodont successions from central Sweden. Geologiska Föreningens i Stockholm Förhandlingar 115: 193-207.

Löfgren, A. 1994. Arenig (Lower Ordovician) conodonts and biozonation in the Eastern Siljan District, Central Sweden. Journal of Paleontology 68 (6): 1350-1368.

Löfgren, A. 1996. Lower Ordovician conodonts, reworking, and biostratigraphy of the Orreholmen quarry. Västergötland, south-central Sweden. Geologiska Föreningens I Stockholm Förhandlingar 118 (3): 169-183.

Mango, M.J.; Albanesi, G.L. 2018a. Bioestratigrafía y provincialismo de conodontes del tramo mediosuperior de la Formación San Juan en el cerro Viejo de Huaco, Precordillera, Argentina. Andean Geology 45 (2): 274-299. doi: 10.5027/andgeoV45n2-3056.

Mango, M.J.; Albanesi, G.L. 2018b. Conodont biostratigraphy from the upper San Juan Formation (Middle Ordovician) at Niquivil, Argentine Precordillera. Journal of South American Earth Sciences 84: 48-55. doi: 10.1016/j. jsames.2018.03.008.

Mango, M.J.; Varini, M.; Albanesi, G. 2016. Biozonas de conodontes de la Formación San Juan (Ordovícico) y cronoestratigrafía de los cadilitos carbonáticos de la Formación Guandacol (Carbonífero) en el anticlinal de Huaco, Precordillera de San Juan. Acta Geológica Lilloana 28 (suplemento): 123-126. Argentina.

Mestre, A. 2008. Revisión bioestratigráfica del techo de la Formación San Juan (Ordovícico Inferior), en la sección del Monumento a Buenaventura Luna, Precordillera Central, San Juan. Acta Geológica Lilloana 20 (2): 127-136.

Nicoll, R.S.; Laurie, J.R.; Roche, M.T. 1993. Revised stratigraphy of the Ordovician (Late Tremadoc-Arenig) Prices Creek Group and Devonian Poulton Formation, Lennard Shelf, Canning Basin. Western Australia. Journal of Australian Geology and Geophysics 14: 65-76.

Ortega, G.; Albanesi, G.L.; Frigerio, S.E. 2007. Graptoliteconodont biostratigraphy and biofacies of the Middle Ordovician cerro Viejo succession, San Juan Precordillera Argentina. Palaeogeography, Palaeoclimatology, Palaeoecology 245: 245-263.

Ortiz, A.; Zambrano, J. 1981. La Provincia geológica Precordillera Oriental. In Congreso Geológico Argentino, No. 8, Actas 3: 59-74. San Luis.
Pohler, S.M.L. 1994. Conodont biofacies of Lower to lower Middle Ordovician Mega- conglomerates, Cow Head Group, Western Newfoundland. Geological Survey of Canada Bulletin 459: 1-71.

Pratt, B.; Raviolo, M.M.; Bordonaro, O.L. 2012. Carbonate platform dominated by peloidal sands: Lower Ordovician La Silla Formation of the eastern Precordillera, San Juan, Argentina. Sedimentology: 843-866.

Ross, R.J., Jr.; Hintze, L.F.; Ethington, R.L.; Miller, J.F.; Taylor, M.E.; Repetski, J.E. 1997. The Ibexian. Lowermost Series in the North American Ordovician (with a section on Echinoderm Biostratigraphy by James Sprinkle and Thomas E. Guensburg). In Early Paleozoic biochronology of the great basin, western United States (Taylor M.E.; editor). U.S. Geological Survey, Professional Paper 1579: 1-50.

Seo, K.-S.; Lee, H.-Y.; Ethington, R.L. 1994. Early Ordovician conodonts from the Dumugol Formation in the Baegunsan syncline, Eastern Yeongweol an Samcheog areas, Kangweon-Do, Korea. Journal of Paleontology 68 (3): 599-616.

Serpagli, E. 1974. Lower Ordovician conodont from Precordilleran Argentina (Province of San Juan). Bolletino della Societa Paleontologica Italiana 13 (1-2): 17-98.

Serra, F.; Albanesi, G.L.; Ortega, G.; Bergström, S.M. 2015. Biostratigraphy and palaeoecology of MiddleLate Ordovician conodont and graptolite faunas of the Las Chacritas River section, Precordillera of San Juan, Argentina. Geological Magazine 152 (5): 813-829.

Smith, M.P. 1991. Early Ordovician conodonts of East and North Greenland. Meddelelser om Grønland Geoscience 26: 1-81.

Stone, J. 1987. Review of investigative techniques used in the study of conodontes. In Conodonts: Investigative Techniques and Applications (Austin, R.L.; editor). Ellis Horwood Limited: 17-34. Chichester.

Stouge, S.; Bagnoli, G. 1988. Early Ordovician conodontes from the Cow Head Peninsula, western Newfoundland. Palaeontographia Italica 75: 89-179.

Stouge, S.; Harper, D.A.T.; Sevastopulo, G.D.; O'Mahony, D.; Murray, J. 2015. Lower and Middle Ordovician conodonts of Laurentian affinity from bloccks of limestone in the Rosroe Formation, South Mayo Trough, western Ireland and their palaeogeographic implication. Geological Journal 51 (4): 584-599.

Szaniawski, H. 1980. Conodonts from the Tremadocian chalcedony beds. Holy Cross Mountains (Poland). Acta Palaeontologica Polonica 25: 101-121

Thalmeier, M.B. 2014. Bioestratigrafía y paleoambientes de conodontes de la Formación San Juan (Ordovícico 
Inferior-Medio) expuesta en el cerro La Silla, Precordillera de San Juan, Argentina. Trabajo Final en Geología (Unpublished), Universidad Nacional de Córdoba, Facultad de Ciencias Exactas, Físicas y Naturales: 1-108.

Tolmacheva, T.Y. 2001. Conodont biostratigraphy and diversity in the Lower-Middle Ordovician of eastern Baltoscandia (St. Petersburg region, Russia) and Kazakhstan. Summary in Ph.D. Thesis (Unpublished), Department of Earth Sciences, Historical Geology and Palaeontology, Uppsala University: 1-40. Sweden.

Voldman, G.G.; Albanesi, G.L.; Ramos, V.A. 2010. Conodont geothermometry of the lower Paleozoic from the Precordillera (Cuyania terrane), northwestern Argentina. Journal of South American Earth Sciences 29 (2): 278-288.

Voldman, G.G.; Albanesi, G.L.; Monaldi, C.R.; Zeballo, F.J. 2013a. An Early Ordovician conodont fauna from the Santa Rosita Formation at its type area in the Santa Victoria Range, Cordillera Oriental, Northwestern Argentina. Stratigraphy 10 (4): 301-322.

Voldman, G.G.; Albanesi, G.L.; Zeballo, F.J.; Monaldi, C.R. 2013b. Early Ordovician (Late Floian) conodonts from the Zenta Range, Cordillera Oriental, NW Argentina. In Conodonts from the Andes. International Conodont Symposium, No. 3 (Albanesi, G.L.; Ortega, G.; editors). Asociación Paleontológica Argentina, Publicación Especial 13: 123-128. Mendoza.

Voldman, G.G.; Albanesi, G.L.; Ortega, G.; Giuliano, M.E.; Monaldi, C. R. 2016. New conodont taxa and biozones from the Lower Ordovician of the Cordillera Oriental, NW Argentina. Geological Journal 52 (3): 394-414. Wang, X.; LI, Z.; Chen, X.; Wang, C. 2003. The Huanghuachang section, potential as Global stratotype for the base of the Middle Ordovician Series. In Ordovician from Andes (Albanesi, G.L.; Beresi, M.S.; Peralta, S.H.; editors). Instituto Superior de Correlación Geológica (INSUGEO), Serie Correlación Geológica 17: 153-159.

Wang, Z.; Zhen, Y.Y.; Bergstrom, S.M.; Zhang, Y.; $\mathrm{Wu}$, R. 2018. Ordovician conodont biozonation and biostratigraphy of North China. Australasian Palaeontological Memoirs 51: 65-79.

Zhen, Y.Y.; Percival, I.G.; Löfgren, A.; Liu, J.-B. 2007. Drepanoistodontid conodonts from the early Ordovician Honghuayuan Formation of Guizhou, South China. Acta Micropalaeontologica Sinica 24 (2): 125-148.

Zhen, Y.Y.; Percival, I.G.; Zhang, Y.D. 2015a. Floian (Early Ordovician) conodont-based biostratigraphy and biogeography of the Australasian Superprovince. Palaeoworld 24 (1-2): 100-109.

Zhen, Y.Y.; Zhang, Y.; Tang, Z.; Percival, I.G.; Yu, G. 2015b. Early Ordovician conodonts from Zhejiang Province, southeast China and their biostratigraphic and palaeobiogeographic implications. Alcheringa: An Australasian Journal of Palaeontology 39 (1): 109-141.

Zhen, Y.Y.; Zhang, Y.; Wang, Z.; Percival, I.G. 2016. Huaiyuan Epeirogeny-shaping Ordovician stratigraphy and sedimentation on the North China Platform. Palaeogeography, Palaeoclimatology, Palaeoecology 448: 363-370. 